\title{
Population trends of birds in alpine habitats at Ammarnäs in southern Swedish Lapland 1972-2011
}

\author{
Beståndsförändringar hos fåglar på kalfjäll runt Ammarnäs i södra svenska \\ Lappland 1972-2011
}

\author{
SÖREN SVENSSON \& THOMAS ANDERSSON
}

Abstract

\begin{abstract}
All birds were counted along six permanent routes (total length $90 \mathrm{~km}$ ) located in the low alpine zone (800-1000 m.a.s.1.) at Ammarnäs, southern Lapland, during fortyyears, 1972-2011. Eighty-three species were recorded; average 41 species and 1677 birds per year. Number of species as well as population size increased for waterfowl, waders and other non-passerines but not for passerines. Thirteen of the thirty-eight most regular species had significant population trends, twelve of them positive. The route counts correlated well with the number of pairs in two adjacent territory mapping plots. The trends also correlated positively with those found in all mountain routes of the Swedish Bird Survey. Although not quite significant this similarity indicates that common largescale factors are involved in governing the local popula-
\end{abstract}

tion changes. Several of the species that have their main distribution at lower levels are expanding their ranges into the alpine zone. Despite the predominance of positive trends some species have more or less severe problems, requiring deeper studies or conservation measures: Melanitta fusca, Aythya marila, Philomachus pugnax, Eremophila alpestris and Plectrophenax nivalis.

Sören Svensson, Department of Biology, Lund university, Ecology Building, SE-223 62 Lund, Sweden. E-mail Soren.Svensson@biol.lu.se.

Thomas Andersson, Önneköp folk high school, Department of natural sciences, Bygatan 30, SE-29173 Önneköp, Sweden.

Received 11 February 2013, Accepted 4 June 2013, Editor: R. Ekblom

Birds of alpine habitats have long featured among the least known as to population densities and trends in Sweden. As late as in the Red List of 2000 (Gärdenfors 2000), two out of four bird species that were classified in the DD (data deficient) category belonged to the alpine region (Long-tailed Duck Clangula hyemalis and Red-throated Pipit Anthus cervinus). The reason for this was that surveys had been conducted at only a few sites, and usually not over many years. When writing the most up-to-date book on bird numbers (Ottosson et al. 2012) it was found that very little new information had been added after the 1980s. Ammarnäs, where the current study was conducted, remains the only site with continuous long term coverage of alpine bird communities (territory mapping of two plots of one square kilometre each since 1964 (Svensson 2006) and of a thirteen square kilometre plot since 1984 (Svensson 2007; only partly published but still going on)). It is only during the most recent decade that the general coverage of the whole alpine region has improved, thanks to the permanent route project of the Swedish Bird Survey
(Svensson 2000, Lindström et al. 2012; also well described in Ottosson et al 2012). There is another long term study in alpine habitat that was active for eighteen years (at Hardangervidda in southern Norway; Østbye et al. 2007), but that study was concluded already in 1984. Recently, Byrkjedal \& Kålås (2012) compared two surveys thirty years apart (1980 and 2010-2011), also at Hardangervidda, and another study with two counts far apart (1978 and 2001) was made by Berg et al. (2004) in the Rautas area in Lapland. Regrettably, these two latter studies are difficult to interpret as the counts have no known variation, and if one of the years is aberrant the conclusions are void from a long term point of view.

The eastern part of the Vindel River Nature Reserve, where Ammarnäs is situated, is by far the most intensively studied part of the alpine and subalpine biomes in Sweden. A long term project started here in 1963 (in several forest types; Enemar et al. 1984, 2004; Andersson \& Sandberg 1996). Apart from surveys of bird abundance, also numerous studies of the ecology and biology of species 
have been completed; a list of publications from the project can be found at www.luvre.org.

When the surveys of the two alpine plots had been done for a few years time, it became evident that the results from such small plots would not be sufficient to monitor the long term trends of more than a handful of species. Nor could it be taken for granted that the small plots were representative for the whole Ammarnäs region or the whole nature reserve and of course much less so for the whole alpine region of Scandinavia. The resource-demanding territory mapping technique precluded expansion with similar plots all over the mountains. In 1972 we therefore established a number of survey routes (also called line transects) that covered much wider areas than the small plots but were walked only once a year. They sample about four hundred square kilometres of the alpine habitats in the eastern part of the reserve. In this paper we report the result of these surveys during the forty years 1972-2011. In the subalpine birch zone, such routes had been used since the project started in 1963 so we already knew that route surveys would add much important information (Enemar \& Sjöstrand 1967, Enemar et al. 2004).
All bird names are listed in Appendix 3: scientific, English and Swedish names. In the running text below we use only English names.

\section{Methods}

Eight routes were established in 1972 within an area of about $30 \times 40$ kilometres with Ammarnäs village approximately in the centre. Of this area, about 400 square kilometres are alpine habitat, that is open heath and mire above the tree line; the routes were distributed within this habitat. Two of the routes, located at Björkfjället north-east of Ammarnäs, were surveyed only in 1972-1974 and are excluded from this analysis (however, counts along these routes were resumed in 2009). The other six routes, with a total length of about 90 kilometres, were surveyed in most of the forty years that have elapsed: in twenty-eight years all routes were surveyed, in five years five routes, in two years two routes, in three years three routes, and in one year (1999) only one route. In 1984 no route at all was surveyed. Figure 1 shows how the routes cover the area. A detailed description of the routes, including
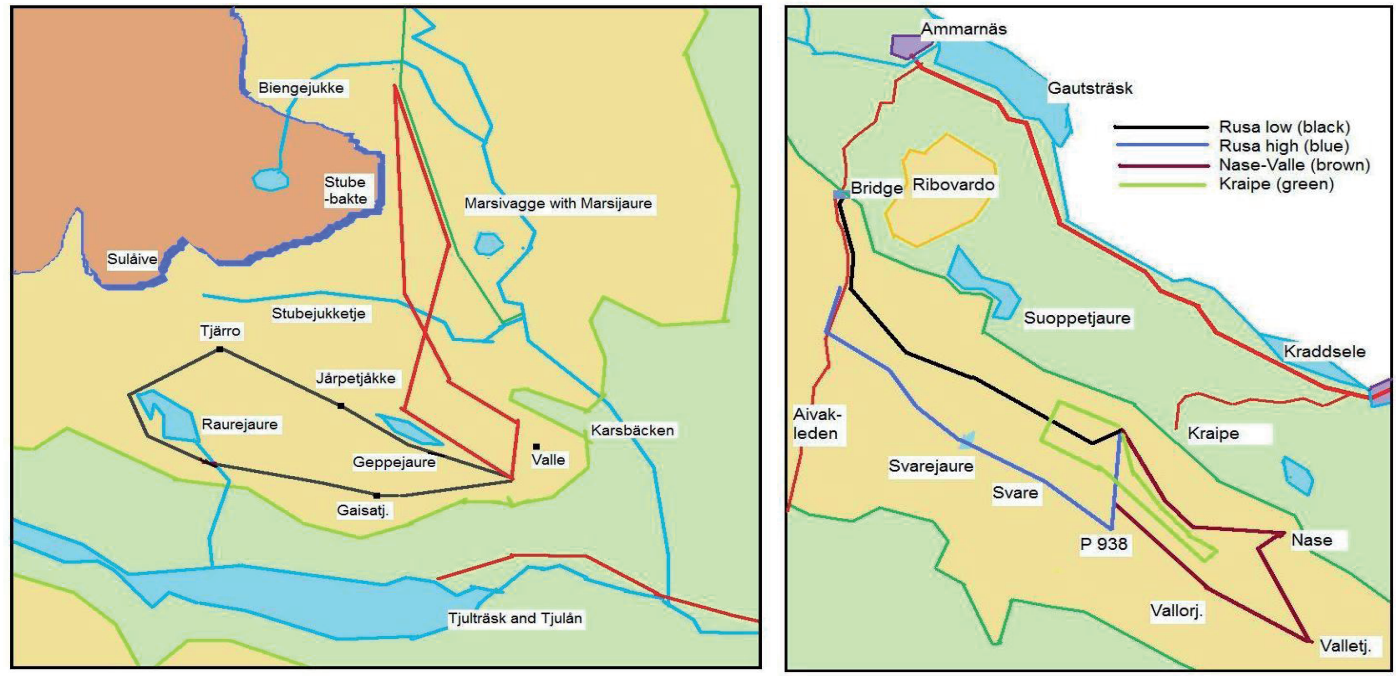

Figure 1. Simplified maps showing the location of the survey routes northwest (left) and south-east (right) of Ammarnäs. Green colour is woodland, blue lakes and streems, light brown alpine areas at elevation less than about $1000 \mathrm{~m}$, and dark brown at higher elevation. The thick, dark blue line in the left map indicates steep cliffs. The left map shows the Stupipakte (red) and Raurejaure (black) routes. The right map shows Ammarnäs and Kraddsele villages, the road along the Vindel river, the dirt road to Kraipe reindeer corall and the Ammarnäs-Aivak trail; route key inset. Route details and coordinates are given in Appendix 1.

Förenklade kartor över inventeringsrutternas placering nordväst (vänster) och sydost (höger) om Ammarnäs. Grön färg anger skog, blå sjöar och vattendrag, ljusbrun fjällhed under 1000 m och mörkbrun fjällhed på högre nivå. Den tjocka blå linjen $i$ den vänstra kartan anger klippstup. Den vänstra kartan visar rutten Stupipakte i rött och rutten Raurejaue $i$ svart. Högra kartan visar byarna Ammarnäs och Kraddsele, vägen längs Vindelälven, vägen till Kraipe rengärde och leden från Ammarnäs mot Aivak; nyckel till rutterna i kartan. Detaljer om rutterna ges i Appendix 1. 
geographical coordinates, is given in Appendix 1. Date, hour, duration and name of the observer is given for each survey in Appendix 2.

The routes were walked slowly and all birds, both males and females, were recorded without any distance limit. Yearlings were automatically excluded as the surveys were made before fledging of young in all species but Raven and Redpoll. No systematic effort was made to include distant birds except when a lake was surveyed or a large or conspicuous bird happened to be discovered far away. Only ordinary binoculars, no spotting scopes, were used. Hence, for most of the smaller land-birds the records emanate from a strip that seldom was more than 200 metres on each side of the route. In spite of that, the detection probabilities of the species are too different to make it possible to compare relative densities of species, and we have not tried to do that in this paper. As all routes went through open heath or mire without taller vegetation, different spatial detection probabilities cannot confound the interpretation of the counts within a species.

If all six routes had been surveyed in all 40 years, 240 counts would have been available. Due to the lack of any surveys in 1984 and the incomplete surveys in other years, the total number of counts is $210(87.5 \%)$. Trends and diagrams are presented for the thirty-eight species that were recorded in at least twenty of the forty years (called regular species). For the remaining species, we only list the records in an appendix.

The trends were calculated with the TRIM programme (Pannekoek \& van Strien 2005). As TRIM cannot handle years with a zero count at all routes, we treated such zero counts in the same way as truly missing counts. The number of additional missing values that was introduced this way varied between species but was never less than the percentages given in the next paragraph on the construction of the diagrams.

For the presentation of bar diagrams of the thirty-eight regular species, complete time series were constructed by imputing values in the following way. For a route that had not been surveyed in a particular year we inserted the average value of the two adjacent years. This means that all values for 1984, when no route was surveyed, were interpolated. In terms of individuals, the birds that had actually been observed constitute about ninety percent of the total of observed and imputed values (82-96\%, depending on species), and of course close to one hundred percent if 1984 and 1999 are disregarded. The imputed birds are shown with a different colour in the bar diagrams.
We compared the data from the Ammarnäs routes with data from four other relevant sources. (1) The first was the local data set from the two small plots that had been surveyed during all forty years in the same alpine habitats at Ammarnäs (Svensson 2006, and unpublished); ten species had sufficient data in both samples. (2) The second source was also a local comparison with similar counts in the subalpine birch zone at Ammarnäs (Enemar 2004, and unpublished); nine species. (3) The third was a comparison with a subset of data from the Swedish Bird Survey (SBS). These data were extracted with the requirement that at least a part of the SBS route should run through alpine or subalpine habitats. A total of 104 routes fulfilled this requirement and 34 species could be included. In these three first comparisons we correlated the species population trend slopes with each other. The SBS trend slopes were calculated with the TRIM programme (Pannekoek \& van Strien 2005) and the slopes based on data from Enemar (2004) and Svensson (2006) with exponential regression (when necessary a zero count was replaced with a small value). (4) The fourth source was the recently published data on waterfowl changes in the mountain range between the early 1970s and 2009 (Nilsson \& Nilsson 2012); eight species. In this waterfowl study two different samples were surveyed by aerial counts. One sample was collected by surveying representative transects that covered all of the mountains once in 1972-1975 and again once in 2009. The other sample was ten special areas selected to reflect typical waterfowl habitats in different regions. The data from the transect sample is not easy to compare with the Ammarnäs data as variance is difficult to assess from only two points in time. For this sample we simply compared the direction of change without any test. The special areas, however, had been surveyed in each of the four years in the early 1970 s. We selected the data from the special areas 1-3 in Nilsson \& Nilsson (2012). These areas are partly identical with areas covered by our own routes or are located adjacent to them. Hence one would expect good agreement. In order to obtain better estimates of variance, we used the five years centred on 2009 for the Ammarnäs routes; hence, the data consisted of four years from each system in the early period and one and five years, respectively, in the late period. ANOVA was used to assess level of significance. After the species accounts we provide the results of and discuss these comparisons.

Temperature data were downloaded from luftweb.smhi.se (Swedish Meteorological and Hy- 
drological Institute) for the position 1525000, 7300000 (RT90 grid) and period 1972-2010. The corresponding values for 2011 were estimated from the SMHI's monthly data sheets.

Statistical test of trends were made with TRIM (Pannekoek \& van Strien 2005, VassarStats.net (CRichard Lowry) and Microsoft Excel. P-values $>0.05$ are considered not significant.

\section{Results}

\section{Number of species and individuals: general patterns}

A total of 83 species was recorded during the forty years of study, with on average 41 species and 1677 individuals per year. The most numerous taxon was the passerines with 31 species $(37 \%)$ and on average 14 species and 1165 individuals $(69 \%)$ per year. The next most common group was the waders in the strict sense (Charadrii) with 17 species (20\%) and on average 12 species and 364 (22\%) individuals per year. The ducks (Anatinae) were important in terms of diversity and counted 12 species (15\%) but on average they were represented with only 6 species and $31(2 \%)$ individuals per year. The other 31 species $(28 \%)$ with a yearly average of 9 species and $110(7 \%)$ individuals was a mixture of several taxa: ten raptors (six Accipitriformes, four Falconiformes), six Larii (three gulls, two terns and the Long-tailed Skua), two grouse (Tetraonini), two loons (Gaviiformes), one Gruidae (Crane), one Strigiformes (Short-eared Owl) and one Cuculidae (Cuckoo). But only seven of these other non-passerine species occurred with an average of more than one individual per year: Rock Ptarmigan, Willow Ptarmigan, Rough-legged Buzzard, Arctic Tern, Mew Gull, Long-tailed Skua and Cuckoo.

The general trends in number of species are shown in Figure 2. The total number of species (not shown in the figure) increased significantly (mean $0.36 \%$ per year; $\mathrm{p}<0.001$ ), corresponding to more than six species in a forty year period. This was mainly a consequence of the trend of the group called other non-passerines which was also significant $(1.1 \% ; p<0.001)$, more than three species in forty years. The number of duck and wader species also increased $(0.7 \%$ and $0.3 \%$ per year) but just barely significantly $(\mathrm{p}<0.05)$. The passerines did not show any significant trend due to a return to the original number of species towards the end of the period after a long period with fewer species.

The trend for number of individuals (Figure $3)$ is positive and significant $(p<0.001)$ for ducks

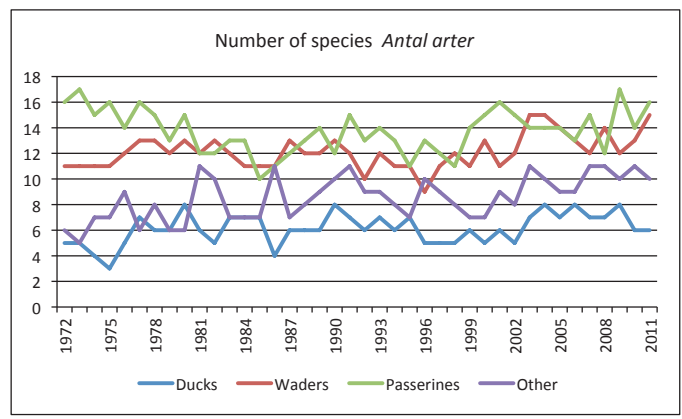

Figure 2. Number of species in different groups: ducks (Anatinae), waders (Charadrinae), passerines (Passeriformes) and other species. The trends are weakly positive $(\mathrm{p}<0.05)$ for ducks and waders and strongly positive $(p<0.001)$ for other species.

Antal arter inom olika grupper: andfåglar (Anatinae), vadarfåglar (Charadrinae), tättingar (Passeriformes) och andra arter. Trenderna är svagt positiva $(p<0.05)$ för andfäglar och vadarfåglar och starkt positiv $(p<0.001)$ för övriga arter.

(2.3\% per year or about $150 \%$ in forty years), waders $(1.5 \%$ per year or about $90 \%$ in forty years) and other non-passerine species $(2.8 \%$ per year or about $200 \%$ in forty years). The trend for the passerines is close to zero and far from significant. And as the passerines are so predominant the trend of the whole community is neither significant. In the group of the twenty-three other non-passerine species twelve occurred in about the same number of

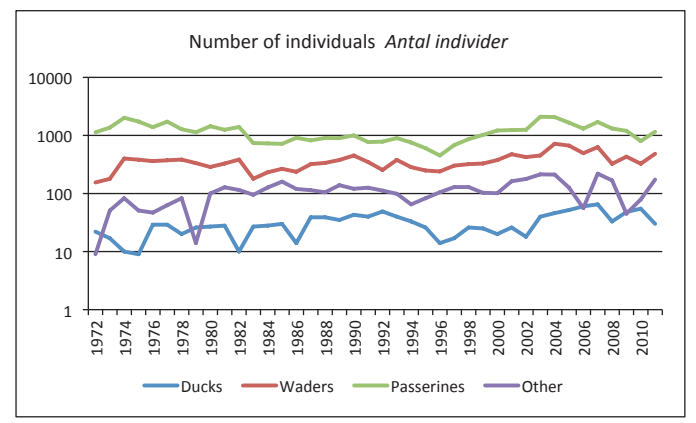

Figure 3. Number of individuals of all species and of species in different groups: ducks (Anatinae), waders (Charadrinae), passerines (Passeriformes) and other species. The linear trends are significantly positive for ducks, waders and other species. The trends for passerines and all species are not significant. The scale is logarithmic in order to show the groups better.

Antal individer av alla arter och av olika artgrupper: andfåglar (Anatinae), vadarfåglar (Charadrinae), tättingar (Passeriformes) och andra arter. De linjära trenderna är signifikant positiva för andfåglar, vadarfåglar och andra arter. Trenderna för tättingar och alla arter är inte signifikanta. Skalan är logaritmisk för att separera kurvorna bättre. 
Table 1. Population trends for the 38 species that were recorded in at least 20 of the 40 years 1972-2011. The number of years with the species absent is given in the rightmost column. Non-significant $p$-values $(\mathrm{p}>0.05)$ are denoted ns.

Populationstrender för de 38 arter som registrerades minst 20 av de 40 åren 1972-2011. Antalet år utan observation ges $i$ kolumnen längst till höger. P-värden som inte är signifikanta $(p>0,05)$ markeras med ns.

\begin{tabular}{|c|c|c|c|c|}
\hline & & Trend & $\mathrm{p}$ & 0 -yrs \\
\hline 1 & Rock Ptarmigan Fjällripa & 1.0337 & $<0.05$ & 4 \\
\hline 2 & Willow Ptarmigan Dalripa & 0.9995 & ns & 6 \\
\hline 3 & Common Teal Kricka & 1.0326 & ns & 9 \\
\hline 4 & Tufted Duck Vigg & 1.0489 & $<0.01$ & 17 \\
\hline 5 & Scaup Bergand & 0.9757 & ns & 8 \\
\hline 6 & Velvet Scoter Svärta & 0.9918 & ns & 9 \\
\hline 7 & Black Scoter Sjöorre & 0.9972 & ns & 7 \\
\hline 8 & Long-tailed Duck Alfågel & 1.0513 & $<0.01$ & 8 \\
\hline 9 & Rough-legged Buzzard Fjällvråk & 0.9954 & ns & 19 \\
\hline 10 & Golden Plover Ljungpipare & 1.0181 & $<0.01$ & 1 \\
\hline 11 & Ringed Plover Sörre strandpipare & 1.0384 & $<0.01$ & 6 \\
\hline 12 & Dotterel Fjällpipare & 1.0112 & ns & 2 \\
\hline 13 & Common Snipe Enkelbeckasin & 0.9909 & ns & 1 \\
\hline 14 & Whimbrel Småspov & 1.0453 & $<0.01$ & 8 \\
\hline 15 & Redshank Rödbena & 1.0532 & $<0.01$ & 2 \\
\hline 16 & Greenshank Gluttsnäppa & 1.0256 & ns & 18 \\
\hline 17 & Wood Sandpiper Grönbena & 1.0683 & $<0.01$ & 9 \\
\hline 18 & Temminck's Stint Mosnäppa & 0.9926 & Ns & 4 \\
\hline 19 & Dunlin Kärrsnäppa & 1.0292 & $<0.01$ & 1 \\
\hline 20 & Ruff Brushane & 0.9934 & ns & 6 \\
\hline 21 & Red-necked Phalarope Simsnäppa & 1.0189 & ns & 1 \\
\hline 22 & Mew Gull Fiskmås & 1.0312 & ns & 1 \\
\hline 23 & Arctic Tern Silvertärna & 1.0100 & ns & 13 \\
\hline 24 & Long-tailed Skua Fjällabb & 1.0332 & ns & 2 \\
\hline 25 & Cuckoo Gök & 1.0251 & $<0.05$ & 1 \\
\hline 26 & Raven Korp & 1.0072 & ns & 1 \\
\hline 27 & Willow Warbler Lövsångare & 1.0093 & ns & 1 \\
\hline 28 & Ring Ouzel Ringtrast & 0.9993 & ns & 12 \\
\hline 29 & Fieldfare Björktrast & 0.9764 & ns & 5 \\
\hline 30 & Redwing Rödvingetrast & 0.9812 & ns & 1 \\
\hline 31 & Bluethroat Blåhake & 1.0012 & ns & 1 \\
\hline 32 & Wheatear Stenskvätta & 1.0163 & $<0.01$ & 1 \\
\hline 33 & Meadow Pipit Ängspiplärka & 1.0005 & ns & 1 \\
\hline 34 & Brambling Bergfink & 1.0270 & ns & 9 \\
\hline 35 & Redpoll Gråsiska & 1.0071 & ns & 1 \\
\hline 36 & Reed Bunting Sävsparv & 1.0225 & $<0.05$ & 1 \\
\hline 37 & Lapland Longspur Lappsparv & 0.9971 & ns & 1 \\
\hline 38 & Snow Bunting Snösparv & 0.9541 & $<0.01$ & 20 \\
\hline
\end{tabular}

years during the first and second half of the period. Only one species occurred in much fewer years (14 versus 1), and that was the Black-throated Loon; one pair in one lake ceased to breed there. Nine species were not recorded at all in the first twenty years but in one or several years during the second twenty years: Crane (in 4 years), Herring Gull (2), White-tailed Eagle (2), and in one year each Gyrfalcon, Marsh Harrier, Common Tern, Common Buzzard and Black-headed Gull. But it was only one species that was recorded in the first half and not in the second half of the period (Peregrine Falcon). Hence, in this group new species outnumbered lost species. In the duck, wader and passerine groups new and lost species were about equally numerous. For example, in the wader group, Greenshank, Bartailed Godwit, Spotted Redshank and Lapwing had 10 and 25 years with records in the first and second part of the period, respectively, versus 22 and 9 for Great Snipe and Common Sandpiper. 
Among the thirty-eight species that had been recorded in at least twenty years, thirteen had population trends that were statistically significant (Table 1). Twelve of these significant trends were positive, whereas only one was negative. It was the order Charadriformes (waders and allies) that contained the most successful species. No less than twelve out of fifteen species of this order had positive trends and six of them were significant. Among the six ducks, three trends were positive and three negative. Two of the positive trends were significant. Among the sixteen remaining species, most of them passerines, ten trends were positive (four of them significant) and six negative (one significant).

Hence, the general pattern of the community can be described as having a stable number of species among ducks, waders and passerines and an increasing number other non-passerine species and increasing populations of ducks, waders and other non-passerine species, but no numerical trend among passerines.

\section{Species accounts}

The detailed occurrence of the thirty-eight most regular species is described with bar diagrams in Figure 4). For most species, the diagram speaks for itself, but nonetheless we give at least a brief comment about each species. For some, the comments are more elaborate, especially if the population change is of interest in relation to conservation, habitat change or climate change. The trends are given in Table 1 together with levels of significance. The records of the remaining forty-five species are given in Appendix 3, but not considered in detail. In all the species diagrams the imputed birds are shown in red and the actually counted birds in blue.

\section{Rock Ptarmigan Lagopus muta (Figure 4, 1)}

The Rock Ptarmigan increased rather erratically to a peak in 2004, with much variation between years. Due to the decline after the peak, the increase for the whole period is only weakly significant. There appear to be no regular population cycles, and the variation does not correlate with small rodent numbers; see a more detailed discussion in the account of Willow Ptarmigan below.

\section{Willow Ptarmigan Lagopus lagopus (Figure 4, 2)}

The two ptarmigans were similar in showing large variation. No correlation between their numbers could be observed $(r=0.24 ; p>0.05$; log values with six zeros replaced by 0.1 ). The Willow Ptarmigan had two peak years, 1982 and 2002. As for the Rock Ptarmigan, it is not possible to see any regular population cycles in the Willow Ptarmigan either. And their major peaks did not coincide. Even with the small samples at hand, one would have expected that some signs of cycles should have been visible in a series of forty years. Data on small rodent abundance at Ammarnäs are available from 1975 (Nyholm 2011). From 1995 there is a new rodent monitoring project at Ammarnäs (Hörnfeldt 2012) with samples collected at more sites and in more habitats than in the Nyholm series. However, during the period 1995-2010, with data available from both, the agreement between the two sampling schemes was almost complete $(r=0.98 ; p<0.001)$ so we use only the longer series of Nyholm for analysing the number of ptarmigans versus rodent abundance. The result is that there is little or no correlation with rodent abundance in the same year or with assumption of one, two or three years of delay. The only correlation was between Willow Ptarmigan and the number of rodents in the previous year, but the significance was weak $(\mathrm{r}=0.44 ; \mathrm{p}<0.05)$.

\section{Teal Anas crecca (Figure 4, 3)}

This is the only dabbling duck that occurs in any numbers above the tree line. Very small water bodies or streams are sufficient. The trend is positive although not significant. The Wigeon (Appendix 3) may become a second regular dabbling duck in the future since it has been recorded almost annually during the last decade (records in eight of the last ten years versus in only six of the previous thirty years). Nilsson \& Nilsson (2012) did not record any significant change in numbers between 1973-1975 and 2009 in their survey. In the whole of Sweden, the Teal population size has not changed since the mid-1980s, but there seems to have been a decline before then (Lindström et al. 2012). However, this decline may have been confined to southern Sweden as only less than one fourth of the population breeds in that part (Ottosson et al. 2012), where most of the data behind the national index were collected.

\section{Tufted Duck Aythya fuligula (Figure 4, 4)}

After a period of absence, 1993-2000, larger numbers than before were recorded, and for the whole period there is a significant increase. The pattern of the Tufted Duck is somewhat similar to those of the Teal and Wigeon. These three species have in common that they predominantly belong 

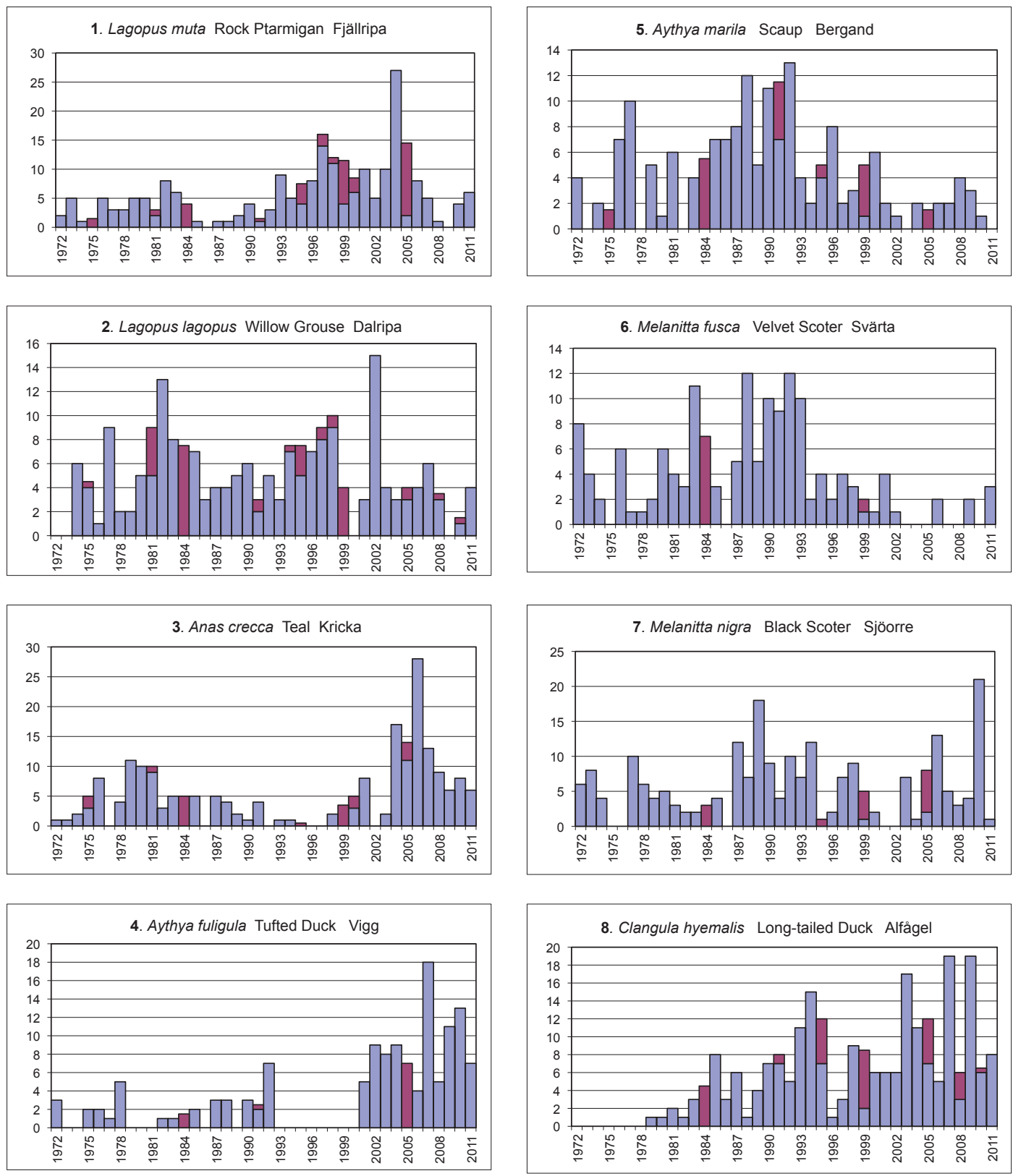

Figure 4. Annual population size for the 38 species that were recorded in at least 20 of the 40 years 1972-2011. Blue: number of individuals actually counted. Red: Estimated additional number of individuals for routes that were not counted.

Arrlig beståndsstorlek för de 38 arter som påträffades under minst 20 av de 40 åren 1972-2011. Blått: antal individer som verkligen räknats. Rött: uppskattat antal individer för rutter som inte räknats. 

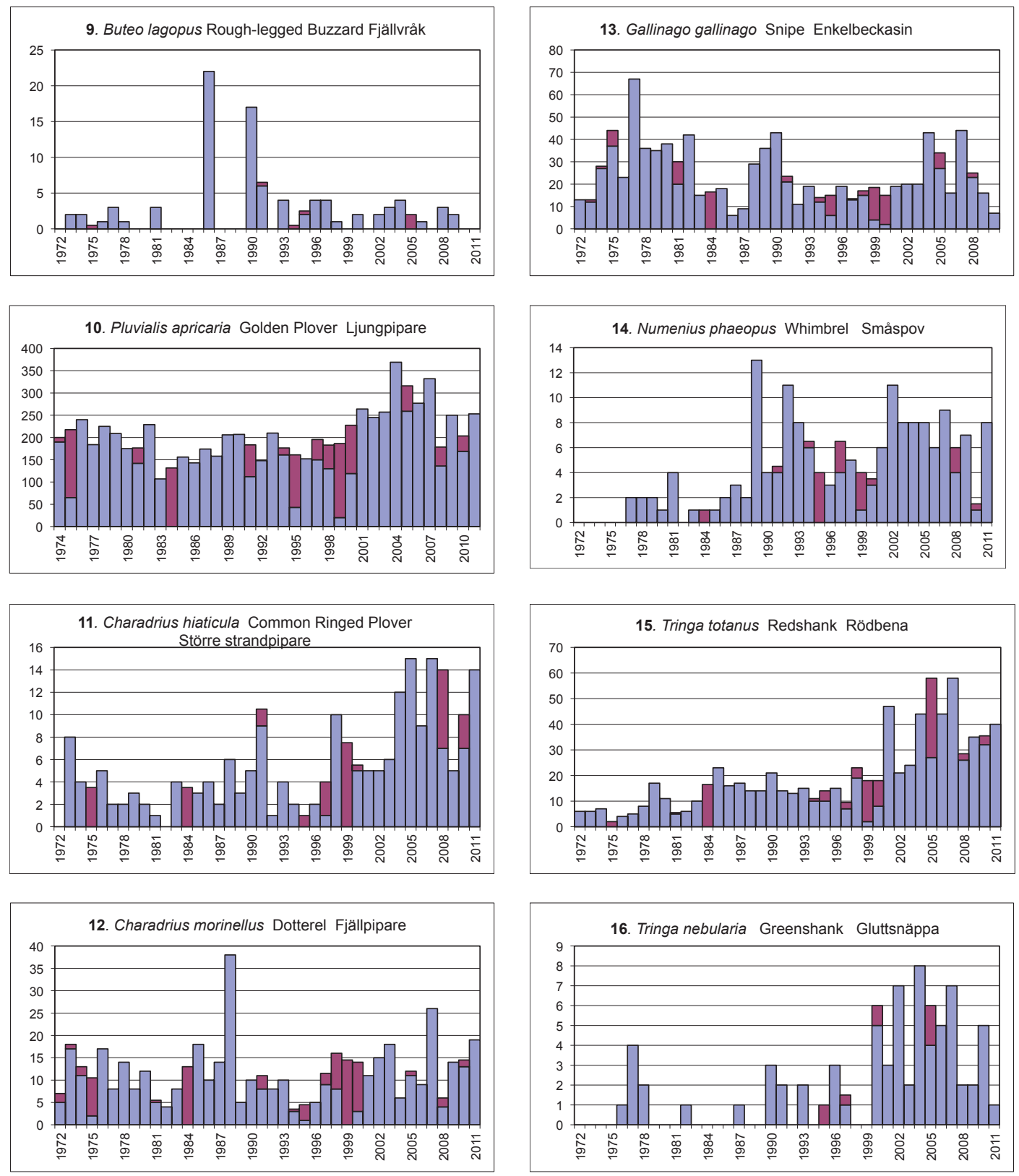

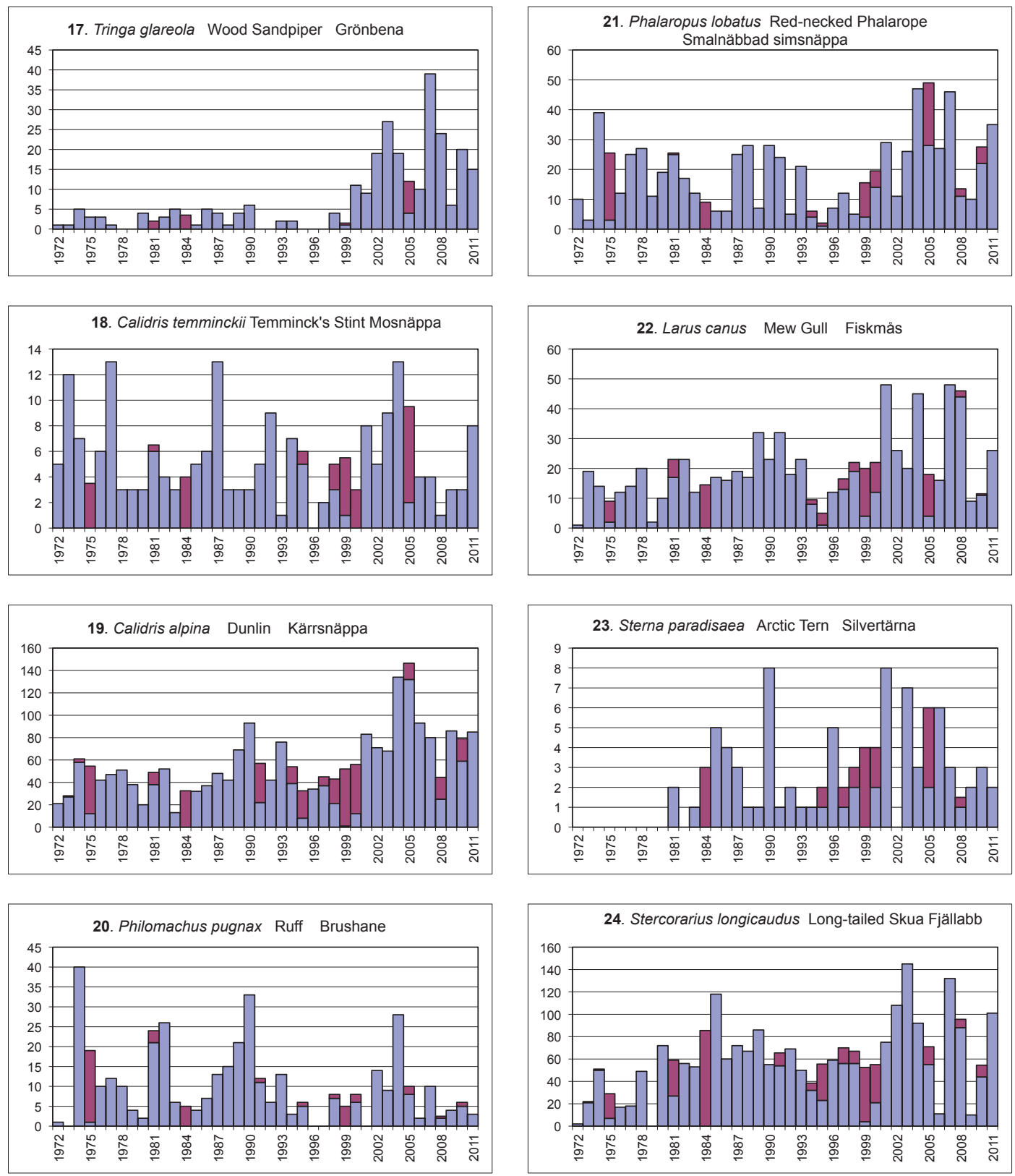

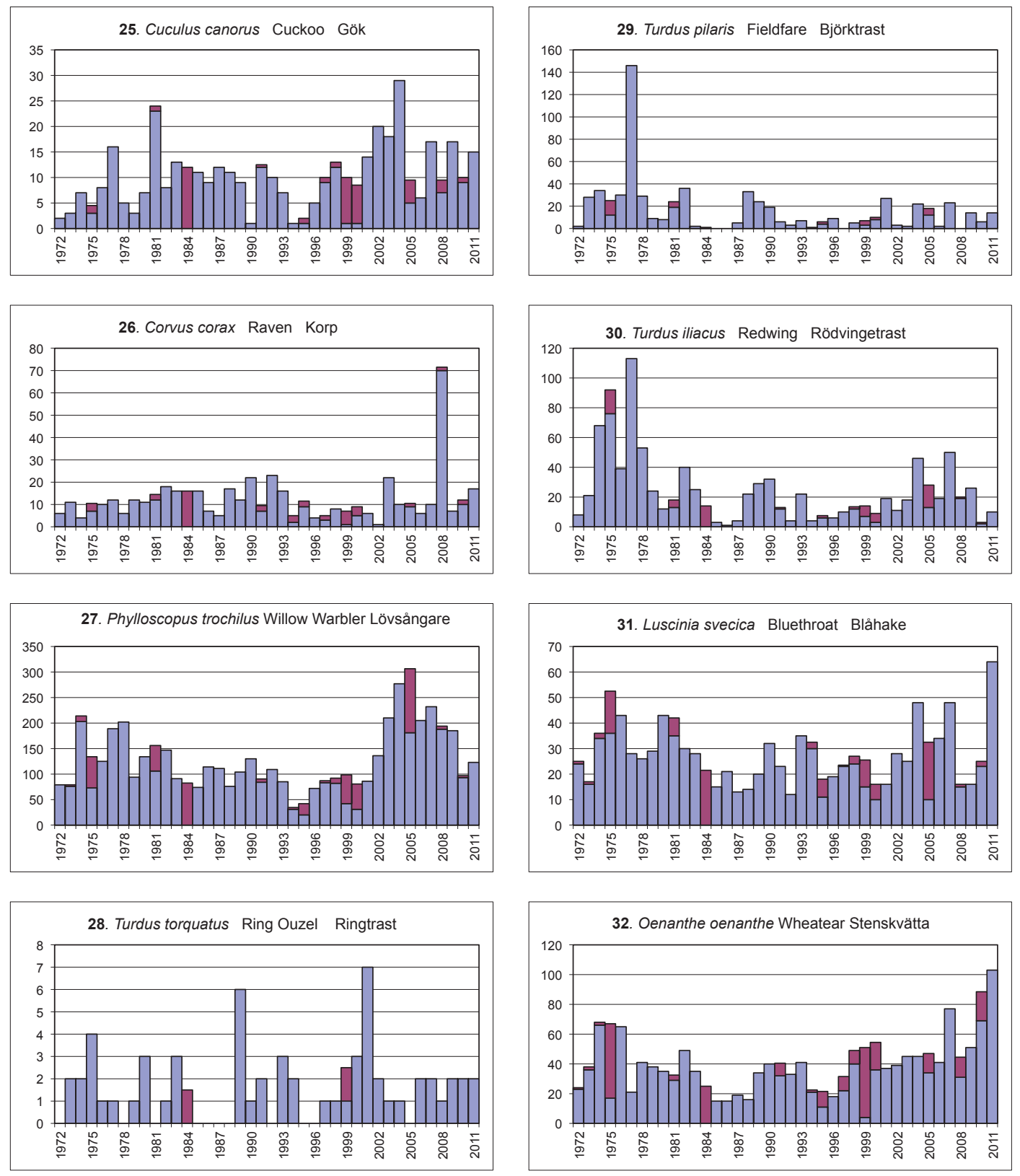

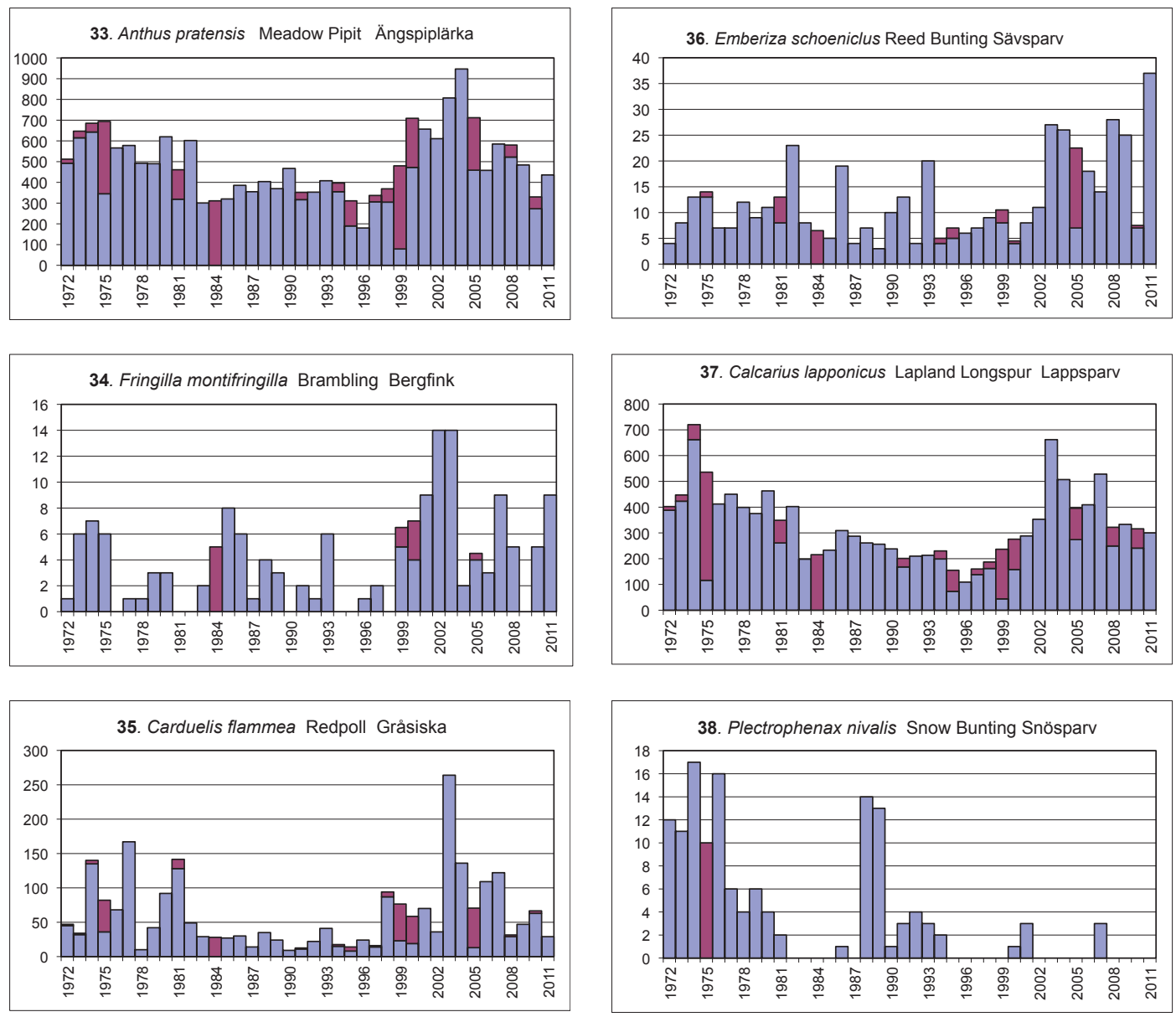
to lower elevations. It is therefore possible that their increases are responses to a more benevolent climate. However, the strong increase at Ammarnäs does not agree with what Nilsson \& Nilsson (2012) found for all alpine and subalpine parts of Sweden, where the change between the early 1970 s and 2009 was small. The absence of records during eight consecutive years is surprising. The Teal also had somewhat lower counts during the same period. As both species are more common at lower levels, difficult ice conditions could be a possible explanation. However, we do not have ice records to support such a conclusion. Furhermore, there is nothing peculiar with these years in the September and January counts in southern Sweden (Nilsson \& Månsson 2011) so severe losses in the winter quarters is an unlikely explanation.

\section{Scaup Aythya marila (Figure 4, 5)}

The number of Scaups has declined drastically after the 1992 peak. However, the long term trend is uncertain because numbers were low also in the early years. Reports on the population trends for this species are ambiguous. According to Tjernberg \& Svensson (2007), the Baltic population of the Scaup declined during most of the twentieth century but a recent survey of the coastal population in the same province as the Ammarnäs sites (Sundström \& Olsson 2005) indicated that the population had increased or remained stable since the 1970s. And Nilsson \& Nilsson (2012) found that little change in numbers had occurred between the early 1970s and 2009 in the alpine region, and this fits with our data at Ammarnäs, where the population size in the early 1970 s was as low as it has been in the 2000 s.

\section{Velvet Scoter Melanitta fusca (Figure 4, 6)}

The long-term trend is uncertain but the Velvet Scoter has been absent along the routes in several recent years. It has declined along the southern Baltic coast of Sweden, a decline of $70-90 \%$ since the 1940s (Tjernberg \& Svensson 2007). However, in the Gulf of Bothnia, at about the latitudes of Ammarnäs, the population has increased (Sundström $\&$ Olsson 2005), and the authors suggest that $40 \%$ of the Swedish coastal population now belong in the province of Västerbotten. As the species has declined in Norway (Bakken et al. 2003), where the population is mainly mountainous, it is probable that the decline at Ammarnäs reflects a general decline of the non-coastal population. This has been corroborated by the counts made by Nilsson \& Nilsson (2012) who recorded a massive decline be- tween the early 1970s and 2009 in the whole alpine and subalpine part of Sweden. Formerly, the Velvet Scoter was widely distributed in the forest region of Finland, and although the early Swedish situation is poorly known it has been suggested that the same distribution prevailed in Sweden (Svensson et al. 1999), perhaps in such a way that the distribution was almost continuous between coast and mountains. Winter counts in the Baltic Sea (Nilsson 2012) and elsewhere indicate a general decline, and the species is now considered to be globally endangered by IUCN. It is difficult to understand why the coastal population of the Gulf of Bothnia is doing better than other populations, but a closer study of this exceptional population could perhaps reveal valuable information about the cause of the general decline.

\section{Black Scoter Melanitta nigra. (Figure 4, 7)}

The Ammarnäs population is stable. For the whole Swedish population, Ottvall et al. (2009) found no change during the preceding thirty years, and the same conclusion was drawn by Valkala et al. (2011) for Finland. The survey by Nilsson \& Nilsson (2012), however, shows a remarkable increase since the early 1970 s in the whole alpine and subalpine part of Sweden. The increase was fourfold during the period of thirty-five years. This corresponds to an average increase of about four percent per year.

Long-tailed Duck Clangula hyemalis. (Figure 4, 8)

The first seven years were without records, but after 1978 this species has been regular and with increasing numbers. Current worries (Nilsson 2012) about the development of the populations that winter in the Baltic Sea may not be relevant for the mountain population and that the reason could be that most birds of this population perhaps winter along the Atlantic coast (Fransson \& Pettersson 2001) where no decline has been observed (Bakken m.fl. 2003). Also the new data from the mountain breeding areas in Sweden (Nilsson \& Nilsson 2012) did not reveal any important change in numbers in the three southern study areas (on average 11 pairs in 1972-1975 versus 13 pairs in 2009). In the northern areas, however, a drastic decline was recorded (the 2009 count, 56 pairs, was only $40 \%$ of that in 1972-1975). But the authors suggest that this low count was a result of the ice situation in 2009, when the high level breeding lakes were not available at the time of the survey. In the absence of good data from other parts of the mountain range we cannot determine whether the increase of num- 
bers at Ammarnäs is a local exception or a reflection of a difference between a healthy Scandinavian mountain population and a global population in difficulty, categorised as vulnerable by IUCN.

Rough-legged Buzzard Buteo lagopus (Figure 4, 9)

The Rough-legged Buzzard is the only raptor that we can monitor, but only with a low quality. After peak years in 1986 and 1990, most likely the result of small rodent peak abundance, really prominent rodent peaks have been almost absent, or suffered crashes before the arrival of birds until 2011. But the Rough-legged Buzzard did not respond, and the reason must be that the absence of good rodent years for so long has made the population level too low to permit it to trace food abundance. A weak response was also recorded in 1977 and 1981, two years with rodent peaks. This lack of a consistent response explains why there is only a weak correlation with the abundance of rodents in the same season $(\mathrm{r}=0.37 ; \mathrm{p}<0.05 ; \mathrm{df}=34$ and no correlation with delayed response of one or two years). The number of autumn migrants at Falsterbo may be a better measure of the general abundance of Rough-legged Buzzards in the mountains. These numbers correlate positively with Ammarnäs rodent abundance in the same year and in the year before $(r=0.39$ and $r=0.38$, respectively; $p<0.05$ in both). But with rodent abundance two years before, the Falsterbo migration is negatively correlated $(\mathrm{r}=0.45 ; \mathrm{p}<0.01)$.

\section{Golden Plover Pluvialis apricaria (Figure 4, 10)}

This is the most abundant wader species in most alpine habitats with typical densities about three pairs per square kilometre (Svensson 2006). The long term trend is positive and significant, and with high numbers during the period 2001-2007. Before that period there was no significant trend. It is one single route, Rusa High, that is responsible for the high totals in the 2000s. We know that the counts along the two high level routes, Rusa High and Nasen, sometimes include flocks of birds that apparently are not involved in incubation or rearing young. They are probably unsuccessful breeders. But these birds must still belong to the local population as migration has not yet started. The recorded increase is likely to be a true reflection of the size shifts of the Ammarnäs population.

Ringed Plover Charadrius hiaticula (Figure 4, 11)

This species has increased dramatically during the 2000s. It is widely distributed at scattered sites with little vegetation and open areas of mud or gravel close to water bodies or streams. It prefers the higher levels where such habitats are most common, and it also breeds above the levels of our highest routes. As a consequence of this, most records come from the Rusa High and Nasen routes, whereas not a single record in all years was made along the route of Rusa Low, a bog and willow scrub route. The alpine population of this species is considered to be a subspecies of its own, tundrae. It is difficult to evaluate whether this strong increase may be connected with events in the breeding or non-breeding areas as the two subspecies have different timing of their migration (Meissner 2007) and different wintering areas, tundrae wintering south of hiaticula (Salomonsen 1955). The latter subspecies seems to have declined, at least in distribution if not also in numbers around the Bothnian Bay both in Sweden and Finland (Valkama et al. 2011).

\section{Dotterel Charadrius morinellus (Figure 4, 12)}

A majority of the records came from the routes Rusa High and Nasen that run at the higher levels that this species prefers. There was no long term population trend. The peak counts in 1988 and 2007, and most of the other variation was most likely variation in display activity. The local population size should not be subject to much variation from year to year as the Dotterel is a long-lived bird and breeding site fidelity is strong (Lücker et al. 2011).

\section{Snipe Gallinago gallinago (Figure 4, 13)}

The Snipe population has shown long term stability. Periodically the counts suggest declines (during the mid 1980s and after the peak in 1990) but numbers have grown again and have been relatively high in some years in the 2000s. With the exception of 1977, the other five peak years have all reached almost an identical level at about forty individuals. The south Swedish population declined very much (to one third) during the period 1975-early 1990s (Lindström et al. 2012), but has been rather stable since then. Note, however, that the two most recent years had very low counts at Ammarnäs, as low as the previous worst years in 1986-1987. And the national index reached its lowest level ever in 2011 after the two decades of no trend. Against the background of generally increasing wader populations the absence of increase in the Snipe population is interesting.

Whimbrel Numenius phaeopus (Figure 4, 14)

This species was formerly breeding at lower el- 
evations where it nested in bogs and forest clearcuts. However, it started to appear above the tree line in the 1970s and has expanded since then, and during the last two decades there has been a rather stable breeding population. The Wimbrel is also increasing nationally (Lindström et al. 2012). Another species of lowland bogs, the Broad-billed Sandpiper Limicola falcinellus, has also expanded into the alpine habitat at Ammarnäs. Although not yet recorded along any of the routes, nests have recently been found in the surroundings of the Raure route (Green et.al. 2009, and unpublished).

\section{Redshank Tringa totanus (Figure 4, 15)}

The Redshank is another wader that has increased its population size in a remarkable way. This increase in the alpine region contrasts sharply with the decline in other parts of Sweden. The point counts of the Swedish Bird Survey, that reflects the development of the population in southern Sweden, suggest an average decline of more than two percent per year since 1975 (Lindström et al. 2012). As about $60 \%$ of all Redshanks belong in Lapland and the adjacent mountains (Ottosson et. al 2012), it is comforting that the alpine trend is so positive. The absence of winter recoveries of Redshanks that are known to have hatched or bred in the alpine area of Scandinavia (Bakken et al. 2003, Fransson et al. 2008) makes it difficult to tell where they spend the winter and hence whether they differ in winter range from southern Redshanks. Long ago Salomonsen (1954) suggested, without much concrete evidence, that Redshanks made the same leap-frog migration as the Ringed Plover, and that the northern populations wintered farthest away, south of the Sahara, and southern populations essentially north of that area. Alerstam (1982) accepted this interpretation based on the morphological analysis of Hale (1973). Were it so, differential winter mortality could explain the contrasting population trends. However, Piersma et al. (1990) suggested that also birds from the North Sea area wintered in considerable numbers in tropical West Africa. Their evidence was only indirect, namely two waves of spring migration away from the winter quarters at Banc d'Arguin in Mauretania. They suggested that these waves represented adaptation to the different seasonal requirements for arrival in their breeding areas of southern and northern birds. If this assumption were correct, considerable numbers of both southern and northern Redshanks may share winter quarters, and it would be difficult to interpret the different population trends in terms of winter survival. Instead it has been argued that the decline of the Redshank populations in southern Sweden is governed by severe depredation of nests due to deterioration of breeding habitats (e.g. overgrazing) as adult survival is high (Ottvall 2005). We may conclude from this that nest depredation ought to be low in the alpine habitats.

\section{Greenshank Tringa nebularia (Figure 4, 16)}

The diagram in Figure 4 gives the impression that the Greenshank should have a significantly increasing trend similar to that of the Redshank and several other waders. However, the trend calculated by using TRIM is not significant. This is a result of the fact that 18 of the first 28 years were without records and that all counts in those years were considered to be missing values instead of zeros. If instead a value of one had been inserted for one of the routes each year the trend would have been significant $(\mathrm{p}<0.05)$. A significant increase is obtained if the trend is calculated by exponential regression on the totals given in the diagram.

\section{Wood Sandpiper Tringa glareola (Figure 4, 17)}

The Wood Sandpiper used to be a very rare species along our routes but has increased remarkably during the 2000 s, following the pattern of the Redshank and most waders. It is a species of lower elevations that obviously has started to expand uphill.

Temminck's Stint Calidris temminckii (Figure 4, 18)

The number of Temminck's Stints varied much but with no long-term trend. Four years with peak counts and with all routes surveyed demonstrated very similar values: 12 (1973), 13 (1977), 13 (1987) and 13 (2004). Raurejaure was the most important route with two thirds of all birds. The mating system of this species (Hildén 1975, Breiehagen 1989), with females that may move in or out of an area between clutches, could complicate the counts. However, males normally stay in their territories to attend the eggs and young of the first brood. The peak years may represent counts that happened to coincide with high display activity at most territories over an extended period, perhaps caused by arrival of new females.

\section{Dunlin Calidris alpina (Figure 4, 19)}

The highest numbers were recorded on the high level routes Rusa High and Nasen. This was not because the breeding density was highest there but because flocks of Dunlins, probably local birds that had failed to breed successfully or refrained from breeding gathered in flocks to prepare for migration. There was a positive long-term trend, and the 
trend remained positive also when the two exceptional peaks of 2004 and 2005 were disregarded. The habit to gather in flocks towards the end of the breeding season is similar to that found in the Golden Plover, and we often saw these two species keep together in such flocks.

\section{Ruff Philomachus pugnax (Figure 4, 20)}

The Ruff showed a non-significant decline. Assuming that the peak numbers in 1974, 1990 and 2004 represent years when a majority of the birds present along the routes were recorded, and using only these three years in the calculation, the decline is about one percent per year. However, counts are sensitive to the time when males display and move about much and the large variation of numbers depends almost completely on this. The dates of the counts coincide with the period of dropping display activity when the males start to leave the area. However, we have no direct indication of a shift to earlier breeding in later years but one must take into account that this may confound the interpretation of the counts (see the general discussion where we deal with temperature changes). We know of no other long-term data from the Swedish mountains. The trend during the last fifteen years has been very negative in the Swedish Bird Survey (Lindström et al. 2012), but the data emanating from the SBS mountain routes are not sufficient to estimate a trend. The Ruff is already almost extinct in southern Sweden so the prospects are really bad.

\section{Red-necked Phalarope Phalaropus lobatus (Figure} 4, 21)

The Phalarope is a rather genuine alpine and subalpine wader without any long term trend but with some similarity with other wades in having several years with high counts in the 2000 s.

\section{Mew Gull Larus canus (Figure 4, 22)}

The trend of the Mew Gull is uncertain but with particularly high numbers in four years in the 2000s. The Mew Gull expanded rather recently in the western mountains. The main expansion period was 1930-1960 (Svensson et al. 1999).

\section{Arctic Tern Sterna paradisaea (Figure 4, 23)}

There was no record during the first nine years. During the remaining thirty-one years there was no significant trend. The number of pairs that breeds along the routes is low, and many of the sparse records are birds that feed away from distant nest sites.
Long-tailed Skua Stercorarius longicaudus (Figure 4, 24)

The increasing trend is not significant. As for the Mew Gull also this species had comparatively low numbers in the early years. Note that the records represent the number of birds that are present at the time of the counts and not the number of breeding birds. The latter number varies from zero to almost one hundred percent of all birds present. Although visiting their potential breeding grounds every spring, the skuas leave the mountains early in the season when rodent levels are low. Years with few skuas (1972, 1979, 2006 and 2009) are years when they had already left when the routes were surveyed. We refrain from analysing the data in terms of rodent abundance as it would be necessary to know the number of nests versus number of non-breeding pairs, and nest search is normally not done during the route counts.

\section{Cuckoo Cuculus canorus (Figure 4, 25)}

Has shown some variation of numbers but it is not known whether this depends on real population variation or on different calling activity. The only important host species in the alpine habitat is Meadow Pipit, and this species has not varied at all to the same extent as the Cuckoo, and there is no correlation between their numbers. Since the alpine habitat is marginal to the Cuckoo it is likely that population size is governed more by events in the forest zone, if at all in the breeding area. Regrettably, we do not have reliable long term data from the Ammarnäs woods for this species. In southern Sweden, the point counts of the Breeding Bird Survey shows a fifty percent decline between 1975 and the late 1980s. The national index from the permanent BBS routes that include also northern Sweden from 2010 indicates some recovery during the most recent decade. BBS data from Lindström et al. (2012).

\section{Raven Corvus corax (Figure 4, 26)}

No long term trend. The aberrantly high number in 2008 depended on large flocks at the routes Stupi and Rusa High. At the time of the counts most Ravens have their young fledged and the birds we record may be visitors from rather far away.

Willow Warbler Phylloscopus trochilus (Figure 4, 27)

The Willow Warbler is the most common species in the birch zone but may be rather common also in the lower part of the alpine zone where fields of willow or junipers cover extensive parts. The number of birds first declined with low numbers 
in the mid 1990s but then returned to a high level in 2003-2008. Our alpine data agree well with the SBS data from north Sweden (the range of the acredula subspecies; $\mathrm{r}=0.67 ; \mathrm{p}<0.001$ ) but not at all with the corresponding data from southern Sweden (the range of the trochilus subspecies.

\section{Ring Ouzel Turdus torquatus (Figure 4, 28)}

This less common species breeds both in the transition zone between the alpine habitat and the birch zone and at rocky sites in the alpine habitat itself. There are several suitable sites along the Stupi and Raure routes where most of the observations were made. No long-term trend could be observed, and no information suggests any population change in a wider geographic perspective.

\section{Fieldfare Turdus pilaris (Figure 4, 29)}

The Fieldfare is abundant in the birch zone where it breeds in colonies (Arheimer \& Svensson 2008). In the alpine zone, where there are no trees, some of the birds are visitors from the forest, but a small number of pairs also breed, and the few nests that have been found have of course been located on the ground. In 1977 numbers were high along all but one route. This was a year with high abundance of Epirrita caterpillars in the alpine zone (Selås et al. 2001). It is likely that this attracted birds from the birch woods. There is no significant long term trend.

\section{Redwing Turdus iliacus (Figure 4, 30)}

Was a rather common breeder in the lower part of the alpine zone in the 1970s but then declined. Somewhat higher numbers have been recorded in the 2000s but the peaks are far from those of the 1970s. The long term trend is not significant.

\section{Bluethroat Luscinia svecica (Figure 4, 31)}

This species is almost endemic to the birch zone but penetrates above it as high as taller willows and junipers grow. In the birch zone, this species has had a negative trend of about four percent per year, with most of this decline in the 2000s. Hence the development of the population in that habitat is different from what we have recorded in the alpine zone where there was no trend.

\section{Wheatear Oenanthe oenanthe (Figure 4, 32)}

The long-term trend is significantly positive but passed through periods of lower numbers in the mid-1980s and mid-1990s. About three fourths of the total Wheatear population breed in the alpine and subalpine part of Sweden (Ottosson et al. 2012). In south Sweden, the population has declined, particularly in farmland, but that decline ceased in the early 1990s; the population has been rather stable since then (Lindström et al. 2012).

Meadow Pipit Anthus pratensis (Figure 4, 33)

The Meadow Pipit was by far the most common species. There was no long-term trend but lower numbers prevailed in the 1980s and 1990s compared with before and after this period. After the good years in the early 2000s the numbers declined to one of the lowest levels ever in 2010.

Brambling Fringilla montifringilla (Figure 4, 34)

The Brambling does not breed above the tree-line but is the next most common species in the subalpine birch zone (Enemar et al. 2004). However, it often visit scattered birches or groups of birches that occur along the lower transects. Other records refer to birds that have been heard singing from a distance at the edges of the wood zone. Since it is not an alpine species, it is also possible that different observers have paid different attention to the Brambling, explaining the variation that is much larger than one would expect from the variation found in the birch zone. The Brambling is clearly a "spill-over" species from the woods, but nonetheless the alpine routes may show a more general pattern as the alpine records correlate well with those from the woodland, mainly because peaks occur in years with much Eppirita larvae (Selås et al. 2001, Lindström et al. 2005).

\section{Redpoll Carduelis flammea (Figure 4, 35)}

Numbers fluctuate much in the birch zone where it breeds abundantly in some years. It also breeds, but with a low density, above the tree line. The birds counted along the routes are a combination of locally breeding birds and probably a larger proportion of birds from the forest. There is much movement of birds whose origin is unknown, and at the time of the counts fledged young from forest habitats below the alpine zone are already on the move. Hence, the numbers do probably not reflect changes in local abundance. Interestingly, however, the pattern shows similarities with several other forest birds with comparatively high numbers in the early and late parts of the survey period. This is one of the very few species in which the alpine and woodland counts correlate significantly.

Reed Bunting Emberiza schoeniclus (Figure 4, 36)

The overall trend was positive. This was due to a sudden increase in the period 2003-2011. In 
southern Sweden a strong decline of two percent per year has been observed since 1975 (Lindström et al. 2012). As much as one half of the national population seems to breed in the alpine and subalpine habitats and adjacent northern areas (Ottosson et al. 2012). This may suggest that it is habitat deterioration in southern Sweden that has caused the decline there.

\section{Lapland Longspur Calcarius lapponicus (Figure 4, 37)}

The Lapland Longspur is one of very few species that is almost exclusively confined to the alpine zone. In many parts of that zone it is one of the most common species; at Ammarnäs it was the next most common one, after the Meadow Pipit. As shown by Svensson (2006) this is not always the case. Although the distribution ranges through the whole mountain chain, local density in habitats that look superficially similarly suitable to the human eye, may vary from zero to high; the densities found at Ammarnäs are the highest recorded in Sweden. It has been suggested that growth of young in this species may depend more on availability of calcium rather than of food (Seastedt \& MacLean 1977). If rich availability of minerals is important for the Lapland Longspur we may have a parallel to the Great Snipe. This species depends on soft basic soils because earthworms thrive there and constitute the most essential kind of food (Løfaldi et al. 1992, Kålås et al. 1997). Longspurs depend on seeds and insects, so the mechanism cannot be the same. However, invertebrate abundance in general is better in basic than in acid habitats. Hence, if Longspurs are particularly sensitive to food variation mediated by minerals the distribution patchiness may at least partly be explained by soil acidity, and the Ammarnäs region is characterized by large areas with calcium-rich bedrock but also by exposure to acid rain (Nyholm 1981). The long-term trend was not significant. The decline from the start of the survey ended in 1996 and turned into a remarkable recovery to the same level as in the 1970s. This same pattern has been observed in several other species.

\section{Snow Bunting Plectrophenax nivalis (Figure 4,} 38)

Our routes run at rather low levels in relation to the main breeding zone of this species, and there are few suitable rocky habitats. Nonetheless, there are a few optimal places for breeding where small colonies existed earlier. These colonies are now gone, and the species is no longer regular along the routes. We believe that the local decline may indicate a more general decline of the species, but we have little information except our own. As the routes do not sample the levels where most birds are breeding we cannot be confident that our counts reflect the real development. Even a small shift of the lower level of occurrence could make a large difference in the counts.

\section{General discussion}

We found good agreement between the results from the Ammarnäs line transects and those from the two territory mapping plots that are situated in close connection with four of the routes (Svensson 2006, and later unpublished counts) for the common period 1972-2011. The small number of pairs and frequent years with no records of most species in the plots made it possible to compare only ten spe-

Table 2. Number of individuals of waterfowl at the routes in Ammarnäs and number of pairs in the three southernmost special study areas in Nilsson \& Nilsson (2012).

Antal individer av sjöfåglar på rutterna i Ammarnäs respektive antal par $i$ de tre sydligaste specialområdena i Nilsson \& Nilsson (2012).

\begin{tabular}{|c|c|c|c|c|c|c|}
\hline & \multicolumn{3}{|c|}{ Ammarnäs routes } & \multicolumn{3}{|c|}{ Southern 3 special areas } \\
\hline & $\begin{array}{r}\text { mean } \\
1972-75\end{array}$ & $\begin{array}{r}\text { mean } \\
2007-11\end{array}$ & p-value & $\begin{array}{r}\text { mean } \\
1972-75\end{array}$ & 2009 & p-value \\
\hline Teal Anas crecca & 2.25 & 8.4 & $<0.01$ & 8.75 & 18 & $>0.10$ \\
\hline Wigeon Anas penelope & 0.00 & 2.6 & $<0.05$ & 9.75 & 30 & $<0.05$ \\
\hline Scaup Aythya marila & 1.75 & 2.0 & $>0.10$ & 55.25 & 49 & $>0.10$ \\
\hline Tufted Duck Aythya fuligula & 1.25 & 10.8 & $<\mathbf{0 . 0 1}$ & 13.50 & 85 & $<0.01$ \\
\hline Long-tailed Duck Clangula hyemalis & 0.00 & 11.0 & $<\mathbf{0 . 0 5}$ & 11.25 & 13 & $>0.10$ \\
\hline Velvet Scoter Melanitta fusca & 3.50 & 1.0 & $>0.10$ & 46.00 & 45 & $>0.10$ \\
\hline Common Scoter Melanitta nigra & 4.50 & 6.8 & $>0.10$ & 56.00 & 275 & $<0.01$ \\
\hline Goosander Mergus merganser & 0.00 & 2.8 & 0.07 & 2.25 & 30 & $<0.001$ \\
\hline
\end{tabular}


cies. All ten correlations (between actual numbers, not de-trended residuals) were positive, and five of them were significant (Meadow Pipit, Lapland Longspur, Willow Warbler, Bluethroat and Ruff). The correlations were approaching significance for Wheatear, Snipe and Dotterel, but close to zero for Dunlin and Golden Plover. The trend slopes of the line transects also correlated significantly with the slopes of the plots $(r=0.74 ; p<0.05)$. We conclude from this that the results from the routes and plots corroborate the gross patterns of each other.

In order to explain the local trends one would like to know whether they are similar to those of the whole alpine region. Data for the Swedish part of the mountains were obtained from the Swedish Bird Survey. Trend slopes of 35 species could be compared for the common period 2002-2011 (SBS data before 2002 not sufficient). The correlation between the slope values of the two data sets is not significant $(\mathrm{r}=0.29 ; \mathrm{p}>0.05)$. A confounding factor in this comparison is that the data from the BBS has been collected in three different habitats, namely alpine tree-less areas (same as in the current study), subalpine birch woods, and upper parts of the coniferous zone. And the period of comparison is brief. But in spite of this we are somewhat surprised that the correlation was not stronger. We have observed no apparent changes of the breeding habitats and all but three of the thirty-eight regular species are only summer visitors. The Ammarnäs populations, therefore, ought to be governed to a large extent by factors outside the breeding season and by large scale factors such as weather. One would have expected such factors to cause different local populations to change in similar ways.

At Ammarnäs we also have reliable data from the subalpine birch zone. A priori one could not predict which of two alternative relations between alpine and woodland birds of the same species that one would find. If density in both habitats were governed by common external factors, the correlation between the habitats would be positive. But it would also be possible that birds shift habitat between years, for example that woodland species tended to breed at higher elevations in years when the conditions there were particularly benevolent, and vice verse. Were this the case, a negative correlation would be expected. Nine species are common enough in both the alpine and subalpine zones for comparison. Five species showed negative, though not significant, correlations (Bluethroat, Willow Warbler, Reed Bunting, Fieldfare and Meadow Pipit). The other four species showed positive correlations, three of them significant: Brambling $(\mathrm{r}=0.47 ; \mathrm{p}<0.01)$, Redpoll $(0.51 ; \mathrm{p}<0.001)$, Redwing $(\mathrm{r}=0.39 ; \mathrm{p}<0.05)$ and Ring Ouzel $(\mathrm{r}=0.25$; $0.05<\mathrm{p}<0.10)$. The correlation between alpine and woodland trends was far from significant. The most likely explanation of the pattern is that fluctuations in the alpine and woodland zones are independent of each other. The significant correlations for two species, Brambling and Redpoll, is likely to depend on the fact that Bramblings do not belong in the alpine habitat but are heard from a distance when they sing in the woodland edge zone and because Redpolls move about so much with their already fledged young that a large proportion of the birds that we count along the alpine routes are birds from the forest zone.

The data from the transect sample of the waterfowl survey of Nilsson \& Nilsson (2012) is not easy to compare with the Ammarnäs data as variance is difficult to assess from only two points in time. But the direction of change, irrespective of the size of change, was different in only one of eight waterfowl that could be compared; the number of Long-tailed Ducks had increased at Ammarnäs but declined in the all mountain transects. The comparison with the special areas in Nilsson \& Nilsson (2012) is summarized in Table 2. Although the sign of change was the same in seven of the eight species, the significant changes were not in the same species to the same degree. However, there is sufficient agreement between the Ammarnäs routes and the three southern special areas to conclude that the results corroborate each other.

In the alpine region, spring weather is a critical factor for the birds. Areas free of snow and, for the waterfowl, open water in lakes and ponds is essential. Wind-exposed hilltops often become free of snow early but the flat heaths and moors below may be covered with thick snow well into June. There is no information on the snow-cover of the alpine area around Ammarnäs, but temperature is an alternative indication of spring arrival. And likely it also indicates the time of snow melting and breake up of ice. At Ammarnäs there was no trend of temperature change for May and June for the period 1972-2011. However, for April there was a significant warming trend. This trend depended exclusively on high temperatures during the most recent ten years. In the thirty years 1972-2001, mean April temperature was -4.6 degrees (s.d. 1.69) without any trend. Then a sudden increase occurred to a mean of -2.6 degrees in 2002-2011, with little variation between years (s.d. 0.92). This difference of two degrees is statistically significant (t-test; $\mathrm{p}<0.001$ ). 
This temperature pattern may be the explanation for the similar timing of higher numbers of three ducks (Wigeon, Teal and Tufted Duck). These three ducks, in contrast to the other ducks, are the least "arctic" ones, belonging predominantly to lakes in the forest region below the tree line. Higher April temperature may make the alpine areas accessible at an earlier date although it is not until a month or so later that the alpine lakes become fully accessible. The declining numbers of Velvet Scoter and Scaup are unlikely to be caused by the recent April temperature increase but rather reflect a general population decline. Another more mountainous species, the Long-tailed Duck, has increased in numbers, and this increase started long before the sudden temperature increase. Whether this April temperature increase can explain the positive trends among the waders is also worth consideration. In five species, Golden Plover, Ringed Plover, Redshank, Greenshank and Wood Sandpiper, higher levels of population numbers occurred almost at the same time as April temperature increased. In the Wimbrel, however, the increase occurred earlier, and in Dunlin, Phalarope and Mew Gull, there is some increase but not equally well timed with the temperature increase. Higher numbers of Willow Warbler and Reed Bunting also coincide with the increasing early spring temperature. It is important to emphasize that the agreement between population increase and April temperature increase could be only a coincidence without causal connection. It remains to be explained how warmer Aprils can affect the number of birds starting to breed a month or more later. Dates of ice brake and melting of snow at the alpine level are needed, and of course a better understanding of how even a small addition of days for breeding can cause a substantial increase in bird numbers.

Date, hour, time spent counting, observer's skill and attention, weather, and activity of the birds affect how many birds that are recorded. For each route we know the first four variables (Appendix 2). All four changed during the forty years. Mean date shifted to be five days earlier, hour of start to four hours earlier, and the time spent counting to one hundred minutes longer. Ideally, one should make a count during the same phase of the breeding cycle and diurnal activity in all years to ensure that birds are equally detectable. This has not been possible because the dates when the counts could be done have been determined by other scheduled activities. Ideally, we should also have determined the relative efficiency of the observers. Since this was not done, we can only hope that the errors introduced by the absence of full standardization only increases stochastic variation without introducing systematic biases.

Although the majority of species of the alpine habitats in the Ammarnäs region are doing well it is important to make clear that some species are doing so badly that they may go locally extinct. Two species, both passerines, belong to this category, namely the Horned Lark and the Snow Bunting. In the former species the case is well known and has been described earlier (Svensson \& Berglund 1994). As our survey transects go through several areas where the Horned Lark was formerly breeding, the results presented in this paper only confirms the earlier conclusions. In the case of the Snow Bunting, the situation is less clear. The surveys do not cover the levels of the typical habitat of the species; only in a few sections the routes touch the lower limit of its altitudinal range. This means of course that even a very insignificant retreat uphill of the range would appear as a drastic decline in our data even if the total numbers in the whole area has remained rather unchanged.

An important question is how our results affect conservation and management of alpine species in the light of the little evidence of deterioration of the bird fauna in the Ammarnäs region. As we did not find any strong correlation between the Ammarnäs time series and the time series from the mountaneous routes of the Swedish Bird Survey, we cannot conclude that similar positive trends would prevail in the whole alpine region. However, in combination with other evidence, we are more confident about at least some of the negative trends. The following species deserve special attention: Velvet Scoter, Scaup, Ruff, Horned Lark and Snow Bunting, either with conservation measures or deeper studies. Generally, our new data from Ammarnäs confirm the current position of the alpine species in the most recent red-list (Gärdenfors 2010). The Scaup, Ruff and Horned Lark are listed as vulnerable, and the Velvet Scoter as near threatened. The Snow Bunting, however, is among the species of least concern. But, as just explained, we are uncertain about its true status in our region.

\section{Acknowledgements}

We appreciate very much the support that the project has obtained since 2008 from the County Administrative Board of Västerbotten. We also thank all the people that have performed the counts (listed in Appendix 2). Most of them have done the 
work, at least partly, as volunteers. Åke Lindström kindly let us use data extracted from the Swedish Bird Survey; the extraction of data and calculation of the trends was done by Martin Green.

\section{References}

Alerstam, T. 1982. Fågelfyttning. Signum, Lund.

Arheimer, O. \& Svensson, S. 2008. Breeding performance of the Fieldfare Turdus pilaris in the subalpine birch zone in southern Lapland: a 20 year study. Ornis Svecica 18: 17-44.

Andersson, T. \& Sandberg, R. 1996. LUVRE - Fåglar och fågelforskning $i$ Vindelfjällen. Lund.

Bakken, V., Runde, O. \& Tjørve, E. 2003. Norsk ringmerkingsatlas. Volume 1. Stavanger museum.

Berg, Å., Emanuelsson, U. \& Rehnberg, M. 2004. Surveys of the birds in the Rautas area in 1978 and 2001 - population changes in an alpine area. Ornis Svecica 14: 159-168.

Breiehagen, T. 1989. Nesting biology and mating system in an alpine population of Temminck's Stint Calidris temminckii. Ibis 131: 389-402.

Byrkjedal, I. \& Kålås, J.A. 2012. Censuses of breeding birds in a South Norwegian arctic-alpine habitat three decades apart show population declines in the most common species. Ornis Norvegica 35: 43-47.

Ekblom, R. \& Carlsson, P. 2007. Beräkning av dubbelbeckasinens Gallinago media bestånd i Sverige baserat på nya inventeringar vid Ånnsjön och Storlien. Ornis Svecica 17: 37-47.

Enemar, A. \& Sjöstrand, B. 1967. The strip survey as a complement to study area investigations in bird census work. Vår Fågelvärld 26: 111-130.

Enemar, A., Nilsson, L. \& Sjöstrand, B. 1984. The composition and dynamics of the passerine bird community in a subalpine birch forest, Swedish Lapland. A 20-year study. Annales Zoologici Fennici 21: 321-338.

Enemar, A., Sjöstrand, B., Andersson, G. \& von Proschwitz, T. 2004. The 37-year dynamics of a subalpine passerine bird community, with special emphasis on the influence of environmental temperature and Epirrita autmnata cycles. Ornis Svecica 14: 63-106.

Fransson, T. \& Pettersson, J. 2001. Svensk ringmärkningsatlas. Volym 1. Naturhistoriska riksmuseet, Stockholm.

Fransson, T., Österblom, H. \& Hall-Karlsson, S. 2008. Svensk ringmärkningsatlas. Volune 2. Stockholm.

Gärdenfors, U. (ed.) 2000. Rödlistade arter i Sverige 2000 - The 2000 Red List of Swedish Species. Artdatabanken, Sveriges lantbruksuniversitet, Uppsala.

Gärdenfors, U. (ed.) 2010. Rödlistade arter $i$ Sverige 2010 - The 2010 Red List of Swedish Species. Artdatabanken, Sveriges lantbruksuniversitet, Uppsala.

Green, M., Hungar, J. \& Rankin, R. 2009. Is the breeding distribution of Broad-billed Sandpipers Limicola falcinellus moving uphill? Ornis Svecica 19: 244-246.

Hale, W.G. 1973. The distribution of the Redshank Tringa totanus in the winter range. Zoological Journal of the Linnean Society 53: 177-236.

Hildén, O. 1975. Breeding system of Temminck's Stint Calidris temminckii. Ornis Fenn. 52: 117-146.

Hörnfeldt, B. 2012. Miljöövervakning av smågnagare. Web- page 2012-12-17: www2.vfm.slu.se/projects/hornfeldt/ index $3 . \mathrm{html}$

Kålås, J.A., Fiske, P. \& Höglund, J. 1997. Food supply and breeding occurrences: the West European population of the lekking great snipe Gallinago media (Latham, 1787) (Aves). Journal of Biogeography 24: 213-221.

Lindström, Å., Green, M. \& Ottvall, R. 2012. Övervakning av fåglarnas populationsutveckling. Arsrapport för 2011. Biologiska institutionen, Lunds universitet.

Nilsson, L. 2012. Distribution and numbers of wintering sea ducks in Swedish offshore waters. Ornis Svecica 22: 39-59.

Nilsson, L. \& Månsson, J. 2011. Inventering av sjöfågel, gäss och tranor $i$ Sverige. Arsrapport för 2010/2011. Biologiska institutionen, Lunds universitet.

Nilsson, L. \& Nilsson, J. 2012. Changes in numbers and distribution of breeding waterfowl in the Swedish mountain chain between 1972-1975 and 2009. Ornis Svecica 22: 107-126.

Lindström, Å., Enemar, A., Andersson, G., von Proschwitz, T. \& Nyholm, N.E.I. 2005. Density-dependent reproductive output in relation to drastically varying food supply: getting the density measure right. Oikos 110:155-163.

Løfaldi, L., Kålås, J.A. \& Fiske, P. 1992. Habitat selection and diet of Great Snipe Gallinago media during breeding. Ibis 134: 35-43.

Lücker, L., Kraatz, S. \& Kraatz, B. 2011. Field notes on the breeding biology of the Dotterel Charadrius morinellus in Norway. Ornis Svecica 21: 109-118.

Meissner, W. 2007. Different timing of autumn migration of two Ringed Plover Charadrius hiaticula subspecies through the southern Baltic revealed by biometric analysis. Ringing \& Migration 23: 129-133.

Nyholm, N.E.I. 1981. Evidence in involvement of aluminium in causation of defective formation of eggshells and of impaired breeding in wild passerine birds. Environmental Research 26: 363-371.

Nyholm, N.E.I. 2011. Dynamics and reproduction of a nestbox breeding population of Pied Flycatcher Ficedula hypoleuca in a subalpine birch forest in Swedish Lapland during a period of 46 years. Ornis Svecica 21: 133-156.

Østbye, E., Hogstad, O., Lien, L., Framstad, E. \& Breiehagen, T. 2007. Structure and dynamics of a high mountain wetland bird community in southern Norway: An 18-year study of waders and gulls. Ornis Norvegica 30: 4-20.

Ottosson, U., Ottvall, R., Elmberg, J., Green, M., Gustafsson, R., Haas, F., Holmqvist, N., Lindström, Å., Nilsson, L., Svensson, M., Svensson, S. \& Tjernberg, M. 2012. Fåglarna i Sverige - antal och förekomst. Sveriges Ornitologiska Förening.

Ottvall, R. 2005. Breeding success and adult survival of Redshank Tringa totanus on coastal meadows in SE Sweden. Ardea 93: 225-236.

Ottvall, R., Edenius, L., Elmberg, J., Engström, H., Greed, M., Holmqvist, N., Lindström, Å., Pärt, T. \& Tjernberg, M. 2009. Ornis Svecica 19: 117-192.

Pannekoek, J. \& van Strien, A. 2005. Trends and indices for monitoring data. Statistics Netherlands.

Piersma, T., Klaassen, M., Bruggemann, H., Blomert, A.M., Gueye, A., Ntiamoa-Baidu, Y. \& van Brederode, N.E. 1990. Seasonal timing of the spring departure of waders from the Banc d'Arguin, Mauritania. Ardea 78: 123-134. Salomonsen, F. 1954. The migration of the European Red- 
shanks. Dansk Orn. Foren. Tidsskr. 48: 94-122.

Salomonsen, F. 1955. The evolutionary significance of birdmigration. Biologiske Meddelelser 22: 1-62.

Seastedt, T.R. \& MacLean, S.F. 1977. Calcium supplements in the diet of nestling Lapland Longspurs Calcarius lapponicus near Barrow, Alaska. Ibis 119: 531-533.

Selås, V., Hogstad, O., Andersson, G. \& von Proschwitz, T. 2001. Population cycles of autumnal moth, Epirrita autumnata, in relation to birch mast seeding. Oecologia 129: 213-219.

Sundström, T. \& Olsson, C. 2005. Västerbottens kustfågelfauna. Inventering av kustfågelbestånden 2001/2002. Meddelande 4/2005, Länsstyrelsen Västerbotten.

Svensson, S. 2000. European Bird Monitoring: geographical scales and sampling strategies. The Ring 22: 3-23.

Svensson, S. \& Berglund, O. 1994. Monitoring of small and endangered bird populations, with special regard to the shore lark Eremophila alpestris. Pp. 153-162 in Bird numbers 1992 (eds. Hagemaijer, E.J.M. \& Verstrael, T.J.). Statistics Nederlands and SOVON. (Proceedings of the 12th International Conference of IBCC and EOAC, Noordwijkerhout, The Nederlands, September $14^{\text {th }}-18^{\text {th }}$, 1992)

Svensson, S., Svensson, M. \& Tjernberg, M. 1999. Svensk fågelatlas. Sveriges Ornitologiska Förening.

Svensson, S. 2006. Species composition and population fluctuations of alpine bird communities during 38 years in the Scandinavian mountain range. Ornis Svecica 16: $183-210$.

Svensson, S. 2007. A survey of non-passerines within 13 square kilometres of low alpine heath at Ammarnäs in Swedish Lapland in 1984-1995 (Swedish, English summary). Ornis Svecica 17: 48-58.

Tjernberg, M. \& Svensson, M. 2007. Artfakta. Rödlistade ryggradsdjur $i$ Sverige. Sveriges lantbruksuniversitet, Uppsala.

Valkama, J., Väpsäläinen, V. \& Lehikoinen, A. 2011. Suomen III Lintuatlas. http://atlas3.lintuatlas.fi

\section{Sammanfattning}

Under fyrtio år, 1972-2011, räknade vi alla fåglar längs sex permanenta rutter på kalfjället runt Ammarnäs i södra Lappland. Rutternas sammanlagda längd är ungefär $90 \mathrm{~km}$. Deras läge framgår av Figur 1 och detaljer om dem finns i Appendix 1. Rutterna upprättades 1972 för att komplettera två provytor som inventerats i samma område sedan 1964. Provytorna är tillsammans bara två kvadratkilometer och utgör därför inte ett tillräckligt stickprov för att mer än ett fåtal allmänna arters populationer kan följas. Med hjälp av rutterna kunde vi få med en större variation av biotoper och därmed få med flera arter samt större stickprov räknat i antal individer.

Rutterna inventerades genom att vi gick långsamt och räknade alla fåglar vi såg och hörde oberoende av avståndet till dem. Alla individer räknades obe- roende av kön. Ungfåglar blev automatiskt uteslutna eftersom de inte var flygga när inventeringarna utfördes. Alla detaljer om själva inventeringarna är samlade i Appendix 2: datum, klockslag, tidsanvändning och inventerarens namn.

Om alla sex rutterna hade inventerats alla fyrtio åren hade vi haft 240 inventeringar att analysera. Emellertid missade vi en del inventeringar av olika skäl. Inga rutter inventerades 1984 och bara en rutt 1999. Sammanlagt blev 210 av de 240 möjliga inventeringarna utförda $(87,5 \%)$.

Totalt registrerade vi 83 arter. I Figur 2 och Figur 3 sammanfattas resultaten för samtliga arter, uppdelat på huvudgrupperna andfåglar, vadarfåglar, tättingar samt övriga icke tättingar. Tättingarna var den mest betydande gruppen med 31 arter (37\%) och i medeltal 14 arter och 1161 individer per år (69\% av den årliga summan av individer). Den näst mest betydande gruppen var vadare (i strikt mening) med 17 arter (20\%) och i medeltal 12 arter och 369 individer (22\%). Andfåglarna var betydelsefulla när det gäller antalet arter (12 arter, 14\%) men inte när det gäller antal individer (i medeltal 6 arter och 31 individer, 2\%). Övriga 23 arter utgjorde en blandning av tio rovfåglar, sex måsfåglar, två ripor, två lommar, trana, jorduggla och gök. Trenderna för antal arter och antal individer totalt och inom var och en av grupperna har analyserats med exponentiell regression. Totala antalet arter ökade med $0,36 \%(p<0,001)$ per år, vilket motsvarar sex arter på fyrtio år. Denna ökning var huvudsakligen en följd av att blandgruppen övriga arter ökade $(1,1 \%$ per år, $p<0,001)$, motsvarande tre arter på 40 år. Antalet arter ökade också bland andfåglar $(0,7 \%$ per år) och vadare ( $0,3 \%$ per år) men dessa ökningar var bara nätt och jämt signifikanta $(\mathrm{p}<0,05)$. Antalet tättingarter förändrades däremot inte, vilket berodde på att antalet $\mathrm{i}$ slutet av fyrtioårsperioden återgick till ungefär samma nivå som i början efter många år med lägre antal.

Trettioåtta av arterna registrerades under minst tjugo av de fyrtio åren. Dessa presenteras i diagram och deras beståndstrender har beräknats. Diagrammen är samlade i Figur 4. Eftersom det finns luckor i inventeringarna har uppskattade värden satts in för dessa luckor. Dessa uppskattade värden har beräknats på följande sätt. För ett år då en viss rutt inte inventerats har vi satt in medelvärdet för de angränsande åren. Det betyder exempelvis att alla värden för 1984 är skatta på detta vis. Efter att dessa skattningar införts har varje års antal summerats. I Figur 4 har staplarna för de verkligen räknade individerna gjorts blå medan staplarna för de skattade individerna gjorts röda. För att beräkna 
trenderna har analysprogrammet TRIM använts (Trends and indices for monitoring data; Pannekoek \& van Strien 2005). Detta program beräknar de statistiskt mest sannolika värdena för de rutter som inte inventerats och beräknar därefter populationstrenden och dess signifikans. De arter som registrerats under färre än tjugo år analyseras inte närmare men samtliga observationer finns summerade i Appendix 3.

Analysen av de numerära trenderna för de 38 vanligaste arterna redovisas i Tabell 1. Det var klar övervikt för positiva trender, 25 positiva och 13 negativa. Tretton av trenderna var signifikanta och bland dessa var övervikten för de positiva trenderna ännu större. Hela 12 av dessa trender var positiva och bara en negativ. Det var bland vadarna och deras närmaste släktingar som de mest framgångsrika arterna fanns. Inte mindre än tolv av femton arter bland dessa hade positiva trender och sex av dessa ökningar var signifikanta. Bland änderna var det lika många positiva som negativa trender, men de två signifikanta trenderna var positiva. Bland tättingarna och övriga icke tättingar var det svag dominans för ökande trender (10 resp. 7) och av fem signifikanta trender var fyra positiva.

Diagrammen för de enskilda arterna i Figur 4 talar i huvudsak för sig själva och behöver knappast mer än några få kommentarer. Hos riporna finns det inga tydliga variationer som skulle kunna tolkas som tre- eller fyraårigt cykliska. Ändå erhölls för dalripan en svagt positiv korrelation med förekomsten av smågnagare $(\mathrm{r}=0,44 ; \mathrm{p}<0,05)$, vars cykler dock under en lång följd av år varit dämpade. Ändernas variationer är svåra att tolka eftersom deras förekomst kan bero på lokala isförhållanden, och dessa har vi inte registrerat. Sjunkande tal för bergand och svärta, åtminstone under senare år, speglar sannolikt på en allmän och vida spridd trend, som tidigare är känd från kustområden. Ökande antal för änder som främst finns på lägre nivåer (kricka, vigg och bläsand) verkar sammanfalla med högre vårtemperaturer (april) under 2000-talet, men orsakssambandet är tveksamt. Bläsanden hör inte till de trettioåtta regelbundna arterna, men har varit nästan årlig det senaste decenniet. Alfågeln har ökat starkt vilket kontrasterar mot utvecklingen av Östersjöns vinterbestånd; möjligen övervintrar fjällens alfåglar i Atlanten utan att beröras av det som händer i Östersjön. Bland vadarna är det överlag ökande eller stabila bestånd. En del av dessa ökningar kan kanske liksom för några änder bestå $\mathrm{i}$ att de börjar häcka på högre nivåer. Även om nedgångarna för enkelbeckasin och brushane inte är signifikanta finns skäl att dra uppmärksam- het till dessa två arter som haft negativa trender i södra Sverige; brushanen är praktiskt taget utgången. Fjällabben uppvisar inte de stora variationer mellan "många" och noll som man skulle ha kunnat vänta sig. Så hade varit fallet om vi räknat häckande par. Men vi räknar alla individer. Fjällabbarna besöker häckningsområdet varje år, men stannar gnagarfria år bara en kortare tid innan de återvänder till Atlanten. Att det ändå finns år med mycket låga värden beror på att labbarna dessa år redan lämnat Ammarnäs när vi gjort inventeringarna. Blåhaken har klarat sig bra och har ett stabilt bestånd på fjällheden. Det är motsatsen till vad som hänt i fjällbjörkskogen i Ammarnäs, där man noterat en fortlöpande nedgång. I början av 1970-talet var tätheten av blåhake i fjällbjörkskogen tre till fyra gånger högre än på fjällheden men har därefter sjunkit till samma låga nivå. Att stenskvättan har ett gott bestånd på fjällheden är glädjande eftersom arten minskat kraftigt i södra Sverige. De två numerärt dominerande arterna, ängspiplärka och lappsparv, uppvisar liknande drag sett över hela perioden. De var talrikare i början och slutet och fåtaligare många av åren däremellan. Snösparven har minskat kraftigt och registreras numera inte varje år. Vi vet dock inte om nedgången beror på en lika kraftig generell nedgång eller om det är fråga om en mindre uppflyttning av nedre förekomstgränsen. Våra rutter går nämligen på lägre nivåer än där snösparvens huvudförekomst finns. Även en marginell nedgång på de lägre nivåerna kan då misstolkas som kraftig även om beståndet högre upp är vid god hälsa.

Vi har jämfört data från våra rutter med data från fyra andra inventeringar.

Ända sedan 1964 har två provytor om vardera en kvadratkilometer inventerats mycket noga med revirkartering. Dessa provytor ligger i anslutning till fyra av rutterna. Tio arter var tillräckligt vanliga för att jämföras. Samtliga tio korrelationer var positiva och fem av dem signifikanta. Korrelationskoefficienten mellan trenderna var också signifikant positiv. De två inventeringarna stöder alltså varandra och vi kan därför anta att de väl beskriver fågelfaunans förändringar på fjällhedarna runt Ammarnäs.

För att undersöka om dessa resultat från Ammarnäs stämmer med var som händer i fjällkedjan i stort jämförde vi trenderna för rutterna med de som erhållits från Svenska Fågeltaxeringens standardrutter. Ännu är det bara ett ganska litet antal rutter som ger användbara data från ren fjällterräng och för att få ett tillräckligt stickprov valde vi att använda alla rutter som till åtminstone någon del gick genom alpin eller subalpin terräng. Antalet rutter 
som uppfyllde kriteriet var 104 och antalet arter som kunde jämföras var 35 . Vi fick en svag positiv korrelation mellan trenderna $(r=0,29 ; \mathrm{p}>0,05)$. Att den inte blev signifikant kan bero på att standardrutterna inkluderar stora mängder fåglar från fjällbjörkskogen och de övre barrskogarna, och det är inte säkert att förändringarna där är desamma som på fjällheden. En annan faktor som försvagade jämförelsen var att bara tio år kunde användas, 2002-2011, eftersom det inte fanns tillräckligt med data från tidigare standardrutter.

I Ammarnäs finns också inventeringar av den subalpina björkskogen sedan 1963. Eftersom få arter är gemensamma kunde bara nio arter analyseras. Fem arter visade negativ korrelation, ingen dock signifikant. De andra fyra arterna visade positive korrelation, av vilka tre var signifikanta: bergfink, gråsiska och rödvingetrast. Utmärkande för dessa tre är att de tillhör björkskogens fauna men ofta rör sig eller fåtaligt även häckar på fjällheden. Ofta flyger de över eller hörs från skogen när man inventerar rutterna. Den positiva korrelationen kan därför helt enkelt spegla det faktum att det egentligen är skogen som vi indirekt inventerar även på fjällheden.

En fjärde jämförelse gjorde vid med en sjöfågelinventering som genomfördes i fjällkedjan 1972 1975 och som sedan upprepades 2009 (Nilsson \& Nilsson 2012). Resultatet redovisas i Tabell 2. Vi fann flera signifikanta överensstämmelser mellan våra rutter och de sjöfågelräkningar som hade utförts i den sydligaste delen av fjällkedjan, där några av områdena för sjöfågelräkning ligger nära Ammarnäs.

I den alpina regionen är vårvädret en kritisk faktor för fåglarna. Snöfria områden och för änderna isfria vatten är nödvändiga. Vi saknar data om snösmältningen och islossningen. Temperaturen bör dock kunna vara ett surrogat. Vi fann att det för Ammarnäs inte fanns någon temperaturtrend för perioden 1972-2011 varken i positiv eller negativ riktning för månaderna maj och juni, de månader som borde vara mest kritiska. Däremot fanns en signifikant positiv trend för april. Denna trend berodde dock helt på höga aprilvärden under de senaste tio åren. Under 30-årsperioden 1972-2001 fanns ingen trend och medeltemperaturen var $-4,6$ grader (s.d. 1,69). Sedan ökade medeltemperaturen plötsligt och under 2002-2011 var den -2,6 grader med ringa variation (s.d. 0,92). Skillnaden på två grader är signifikant (t-test; $\mathrm{p}<0,001)$.

Man kan spekulera om, som redan antytts, att denna temperaturhöjning är orsaken till att en del arter ökat i antal samtidigt som andra arter som tillhör lägre nivåer börjat flytta upp på fjällheden. Men bilden är minst sagt mångtydig. Och det är inte lätt koppla väderförändringar som sker i april med fåglarnas häckningsstart som inte sker förrän i juni. Nästan alla arter på fjällheden är flyttfåglar och det som händer i vinterkvarteren kan därför vara viktigare än förhållandena på fjället. Sambandet mellan högre apriltemperatur och ökande bestånd hos många fjällfåglar i Ammarnäs kan därför vara en tillfällighet utan orsakssamband.

Trots den positiva utvecklingen av fågelfaunan på fjällhedarna runt Ammarnäs är det viktigt att påpeka att det går så dåligt för vissa arter att de kan försvinna lokalt. Två tättingar, berglärka och snösparv, hör till denna kategori. Berglärkans nedgång är känd sedan länge. Vad gäller snösparvens nedgång är den tydligt i vårt material, men som nämnts tidigare vet vi inte om nedgången även gäller högre fjällterräng. Utvecklingen måste dock ses som en varningssignal och kräver närmare studium. Om vi ser till den svenska rödlistan stämmer resultaten från Ammarnäs tämligen väl. Berganden, brushanen och berglärkan är upptagna som sårbara och svärtan som nära hotad. Snösparven listas dock som en art som inte är utsatt för någon risk, men som sagt är uppgifterna från Ammarnäs osäkra. 


\section{Appendix 1. Description of the permanent survey routes with coordinates of waypoints \\ Beskrivning av de permanenta rutterna med koordinater för orienteringspunkter}

The coordinates refer to the Swedish national grid (RT90) with the N-S coordinate first.

\section{Stupipakte}

This route runs at elevations between 700 and $840 \mathrm{~m}$. Most of the route is scrub heath, partly with dense and tall willow but mostly with rather low willow and dwarf birch. A few sections are rather dry without taller scrub and there are many small bogs. A few scattered birches occur at two patches. The total length of the route is c. $18 \mathrm{~km}$. A part of the route runs just east of the border to the Marsivagge bird protection area. There are only two lakes that affect the counts, contributing some waterfowl, namely Geppejaure and Marsijaure, the latter only marginally because of great distance from the route. Coordinates: 7320170, 1512055; 7320967, 1512137; 7321279, 1512131; 7321681, 1511383, 7322060, 1510882; 7323616, 1510023; 7327577, 1509711; 7324673, 1510706; 7321570, 1510230; 7320170, 1512055 .

\section{Raurejaure}

This route is about $15 \mathrm{~km}$ long and the elevation varies between $814 \mathrm{~m}$ (Raurejaure) and 1034 (peak of Tjärro). The scrub is lower than along the Stupipakte route but there are some sections with fairly tall willow, juniper and dwarf birch scrub. In addition to Raurejaure and Geppejaure there are numerous smaller water bodies, making this route the one that contributes the greatest number of waterfowl. Coordinates: 7320000, 1512000; 7320100, $1508650 ; 7320200,1506950 ; 7320600,1506000 ; 7321700,1505200 ; 7322500,1506900 ; 7320000,1512000$.

\section{Rusa low}

The first section runs almost along a straight line at an elevation of $800-850 \mathrm{~m}$. The habitat is a mosaic of bogs, dry heath and sections with tall willow. The second section continues along a trail that slowly drops towards the forest line, so that the last section also collects birds that are typical for the birch zone. The route is c. $15 \mathrm{~km}$ long. Coordinates: 7304000, 1525900; 7303800, 1524500; 7306500, 1520300; 7307500, 1517700; 7309500, 1516200; 7312800, 1516200 .

\section{Rusa high}

Apart from the first section that runs through bogs with much scrub and willows at elevations between 800 and $900 \mathrm{~m}$, the remaining part of the route runs at 900-1000 $\mathrm{m}$ with poor wind-exposed vegetation. There is only one lake, Svarejaure, with a few waterfowl. The route is $15 \mathrm{~km}$ long. Coordinates: 7303920, 1525840; 7301400, 1524600; 7304600, 1520400; 7305400, 1518500; 7306600, 1517700; 7304000, 1525900; 7309500, 1516200.

\section{Nasen}

The route is c. $18 \mathrm{~km}$ long. The first part runs over boggy habitats with patches of dry scrub heath. The rest of the route has mostly low and rather dry scrub. There is very little tall willow vegetation. Elevation is between 790 and $918 \mathrm{~m}$. Coordinates: 7303920, 1525840; 7303650, 1525800; 7302400, 1526300; 7301200, 1527100; 7301150, 1529700; 7300800, 1529400; 7297620, 1530800; 7299250, 1527500; 7302200, 1524470.

\section{Kraipe}

This is a rather short route, only $9.5 \mathrm{~km}$, running at elevations between 790 and $880 \mathrm{~m}$, and in rather boggy terrain with mostly a well developed scrub layer and rather large patches of taller willow fields. Coordinates: 7303920, 1525840; 7303650, 1525800; 7302250, 1526300; 7301340, 1527380; 7300900, 1527600; 7302600, 1525700; 7303530, 1524340; 7304700, 1524800; 7304200, 1525200; 7303920, 1525840. 


\section{Appendix 2. Basic surves data}

Grundläggande inventeringsdata

Date (D), hour of start (S), duration in minutes (M), and the name of the observer (C) for each survey. Date is given as day from 1 June; thus date values larger than 30 refer to July dates.

Datum (D), timme för start (S), tidsåtgång $i$ minuter $(M)$ och observatörens namn (C) för varje inventering. Datum anges som dag från 1 juni, datum större än 30 avser således juli.

\begin{tabular}{|c|c|c|c|c|c|c|c|c|c|c|c|c|c|c|c|c|c|c|c|c|c|c|c|c|}
\hline \multirow[t]{2}{*}{ Year } & \multicolumn{4}{|c|}{ Stupipakte } & \multicolumn{4}{|c|}{ Raurejaure } & \multicolumn{4}{|c|}{ Rusa low } & \multicolumn{4}{|c|}{ Rusa high } & \multicolumn{4}{|c|}{ Nasen } & \multicolumn{4}{|c|}{ Kraipe } \\
\hline & D & S & M & C & D & S & M & C & D & $\mathrm{S}$ & M & $\mathrm{C}$ & D & $\mathrm{S}$ & M & C & D & $\mathbf{S}$ & M & C & D & $\mathrm{S}$ & $\mathbf{M}$ & $\mathrm{C}$ \\
\hline 1972 & 24 & 11 & 300 & & 24 & 11 & 320 & $\mathrm{C}$ & 28 & 10 & 270 & -1 & 28 & 13 & 235 & $\mathrm{C}$ & 31 & 9 & 385 & $\mathrm{C}$ & 33 & 10 & 210 & $\mathrm{~S}$ \\
\hline 1973 & 26 & 11 & 295 & $\mathrm{~S}$ & 26 & 10 & 370 & $\begin{array}{ll}\mathrm{C} \\
\end{array}$ & 31 & 11 & 255 & $\mathrm{~S}$ & 32 & 11 & 235 & $\mathrm{C}$ & 31 & 11 & 385 & $\mathrm{C}$ & 36 & 11 & 195 & $\mathrm{~S}$ \\
\hline 1974 & 22 & 10 & 305 & & 22 & 10 & 370 & C & 29 & 10 & 265 & & 29 & 11 & 240 & $\mathrm{C}$ & 31 & 9 & 385 & C & 32 & 10 & 195 & $\mathrm{~S}$ \\
\hline 1975 & 29 & 11 & 300 & $\bar{S}$ & 30 & 10 & 360 & $\mathrm{H}$ & 30 & 10 & 285 & $\bar{S}$ & - & 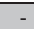 & - & - & - & - & - & - & -1 & - & - & - \\
\hline 1976 & 21 & 10 & 315 & & 21 & 10 & 380 & C & 32 & 9 & 255 & & 26 & 10 & 320 & $\mathrm{C}$ & 32 & 9 & 400 & $\mathrm{C}$ & 26 & 10 & 200 & $\bar{S}$ \\
\hline 1977 & 28 & 9 & 345 & S & 28 & 9 & 385 & C & 26 & 10 & 280 & S & 32 & 9 & 310 & $\mathrm{C}$ & 33 & 10 & 405 & C & 32 & 10 & 200 & $\mathrm{~S}$ \\
\hline 1978 & 22 & 9 & 395 & & 22 & 9 & 385 & C & 32 & 10 & 280 & S & 31 & 9 & 325 & $\mathrm{C}$ & 32 & 10 & 410 & $\mathrm{C}$ & 31 & 9 & 180 & $\mathrm{~S}$ \\
\hline 1979 & 23 & 10 & 345 & $\underline{S}$ & 23 & 10 & 395 & $\mathrm{C}$ & 24 & 9 & 275 & $\underline{S}$ & 29 & 9 & 310 & $\mathrm{C}$ & 35 & 9 & 400 & $\mathrm{C}$ & 29 & 9 & 185 & $\bar{S}$ \\
\hline 1980 & 22 & 9 & 345 & & 22 & 9 & 390 & C & 23 & 10 & 275 & S & 23 & 10 & 315 & C & 25 & 7 & 420 & C & 25 & 10 & 185 & $\mathrm{~S}$ \\
\hline 1981 & 20 & 9 & 370 & & 22 & 9 & 315 & $\mathrm{~N}$ & & - & & - & 21 & 9 & 320 & $\mathrm{~L}$ & 20 & 9 & 405 & $\mathrm{~L}$ & - & 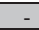 & & - \\
\hline 1982 & 28 & 9 & 325 & $\bar{S}$ & 28 & 9 & 415 & \begin{tabular}{|l|}
$\mathrm{C}$ \\
\end{tabular} & 33 & 9 & 280 & S & 29 & 9 & 320 & $\mathrm{C}$ & 26 & 9 & 445 & C & 29 & 9 & 200 & $\bar{S}$ \\
\hline 1983 & 23 & 9 & 360 & $\mathrm{~S}$ & 20 & 4 & 300 & S & 22 & 10 & 245 & S & 25 & 9 & 310 & $\mathrm{~L}$ & 23 & 9 & 345 & L & 25 & 9 & 180 & S \\
\hline 1984 & - & - & - & - & - & - & - & - & 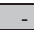 & 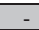 & - & - & - & - & - & - & - & - & - & - & - & - & - & - \\
\hline 1985 & 26 & 8 & 335 & & 33 & 8 & 295 & S & 29 & 10 & 260 & S & 22 & 11 & 290 & $\mathrm{~L}$ & 24 & 9 & 340 & $\mathrm{~L}$ & 22 & 11 & 195 & $\overline{\mathrm{S}}$ \\
\hline 1986 & 22 & 9 & 365 & & 27 & 8 & 280 & $\mathrm{~S}$ & 31 & 10 & 295 & $\underline{S}$ & 22 & 10 & 305 & $\mathrm{~L}$ & 20 & 9 & 345 & $\mathrm{~L}$ & 25 & 11 & 185 & $\mathrm{~S}$ \\
\hline 1987 & 29 & 9 & 320 & & 24 & 9 & 275 & $\mathrm{~S}$ & 31 & 10 & 275 & S & 23 & 7 & 315 & $\mathrm{~L}$ & 24 & 9 & 335 & L & 23 & 11 & 190 & S \\
\hline 1988 & 21 & 8 & 375 & $\bar{S}$ & 24 & 7 & 390 & $\mathrm{~L}$ & 27 & 6 & 285 & S & 22 & 7 & 305 & $\mathrm{~L}$ & 19 & 10 & 295 & $\mathrm{~L}$ & 29 & 8 & 175 & $\mathrm{~S}$ \\
\hline 1989 & 28 & 7 & 385 & & 27 & 7 & 395 & $\mathrm{~L}$ & 32 & 6 & 300 & 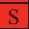 & 25 & 7 & 305 & $\mathrm{~L}$ & 22 & 6 & 385 & L & 27 & 7 & 215 & $\mathrm{~S}$ \\
\hline 1990 & 21 & 6 & 375 & S & 19 & 5 & 415 & $\mathrm{~S}$ & 24 & 8 & 295 & S & 34 & 9 & 310 & $\mathrm{~S}$ & 16 & 7 & 400 & G & 28 & 10 & 230 & $\mathrm{~S}$ \\
\hline \begin{tabular}{|c|}
1991 \\
\end{tabular} & 23 & 6 & 395 & $\bar{S}$ & 24 & 6 & 370 & $\mathrm{~S}$ & 29 & 6 & 350 & $\mathrm{~S}$ & - & - & - & - & 24 & 6 & 495 & $\mathrm{~L}$ & 27 & 6 & 205 & $\bar{S}$ \\
\hline 1992 & 19 & 6 & 380 & & 24 & 7 & 340 & $\mathrm{~S}$ & 31 & 7 & 305 & & 25 & 6 & 325 & $\mathrm{~L}$ & 24 & 6 & 375 & $\mathrm{~L}$ & 18 & 10 & 210 & $\bar{S}$ \\
\hline 1993 & 22 & 6 & 405 & S & 27 & 7 & 345 & $E$ & 27 & 6 & 270 & S & 27 & 6 & 300 & L & 24 & 8 & 365 & L & 22 & 6 & 225 & $\mathrm{~S}$ \\
\hline 1994 & 18 & 7 & 440 & $\bar{S}$ & 16 & 8 & 360 & I & 21 & 7 & 355 & $\mathrm{I}$ & 33 & 8 & 360 & $E$ & 29 & 10 & 335 & $\mathrm{~L}$ & - & - & - & - \\
\hline 1995 & 20 & 7 & 405 & S & 31 & 9 & 390 & \begin{tabular}{|l|}
$\mathrm{Y}$ \\
\end{tabular} & - & - & - & - & - & - & - & - & - & - & - & - & 28 & 5 & 235 & S \\
\hline 1996 & 19 & 6 & 405 & & 24 & 8 & 330 & I & 24 & 6 & 310 & S & 25 & 6 & 345 & S & 28 & 6 & 360 & $\mathrm{~S}$ & 22 & 10 & 210 & S \\
\hline 1997 & 23 & 6 & 360 & $\mathrm{P}$ & 19 & 7 & 380 & I & 26 & 6 & 405 & $\mathrm{R}$ & 24 & 7 & 330 & $\mathrm{~A}$ & 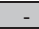 & - & - & - & 25 & 5 & 240 & $\underline{S}$ \\
\hline 1998 & 28 & 6 & 345 & $P$ & 22 & 6 & 370 & S & 25 & 6 & 375 & $\mathrm{~S}$ & - & - & - & - & 24 & 6 & 390 & $\mathrm{~S}$ & 20 & 10 & 255 & $S$ \\
\hline 1999 & 23 & 5 & 375 & Q & - & - & - & - & - & - & - & - & - & - & - & - & - & - & - & - & - & - & - & - \\
\hline 2000 & 34 & 8 & 430 & A & 29 & 9 & 375 & $\mathrm{R}$ & - & - & - & - & - & - & - & - & 36 & 7 & 415 & A & - & - & - & - \\
\hline 2001 & 25 & 5 & 480 & $\mathrm{~S}$ & 25 & 6 & 465 & A & 31 & 5 & 465 & $\mathrm{~A}$ & 27 & 5 & 450 & A & 34 & 5 & 450 & A & 24 & 5 & 200 & $\overline{\mathrm{A}}$ \\
\hline 2002 & 28 & 6 & 470 & $\mathrm{~A}$ & 19 & 9 & 345 & $\mathrm{~S}$ & 26 & 5 & 390 & $\mathrm{~A}$ & 25 & 6 & 445 & $\mathrm{~T}$ & 25 & 6 & 450 & A & 21 & 7 & 256 & S \\
\hline 2003 & 27 & 6 & 460 & $\mathrm{~T}$ & 27 & 6 & 420 & A & 25 & 6 & 345 & $\mathrm{~A}$ & 23 & 6 & 480 & $\mathrm{~T}$ & 29 & 8 & 450 & $\mathrm{~A}$ & 21 & 11 & 205 & $\underline{S}$ \\
\hline 2004 & 22 & 6 & 500 & T & 22 & 6 & 470 & A & 20 & 6 & 460 & $\mathrm{~A}$ & 20 & 6 & 500 & $\mathrm{~T}$ & 28 & 6 & 445 & $\mathrm{~A}$ & 19 & 6 & 245 & S \\
\hline 2005 & & - & & - & - & - & & 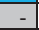 & 23 & 5 & 410 & $\mathrm{~A}$ & 23 & 5 & 265 & $\mathrm{~T}$ & 29 & 5 & 350 & A & 19 & 7 & 240 & S \\
\hline 2006 & 27 & 5 & 445 & $\mathrm{~T}$ & 27 & 5 & 480 & A & 21 & 6 & 405 & $\mathrm{~A}$ & 21 & 6 & 425 & $\mathrm{~T}$ & 29 & 6 & 400 & A & 24 & 7 & 200 & A \\
\hline 2007 & 25 & 6 & 470 & $\mathrm{~T}$ & 25 & 6 & 382 & $\mathrm{M}$ & 20 & 6 & 410 & $\mathrm{~A}$ & 20 & 6 & 445 & $\mathrm{~T}$ & 25 & 6 & 445 & $\mathrm{~A}$ & 24 & 6 & 180 & $\mathrm{~A}$ \\
\hline 2008 & 22 & 6 & 525 & $\mathrm{~T}$ & 22 & 6 & 455 & $\mathrm{~A}$ & 27 & 5 & 405 & $\mathrm{~A}$ & 27 & 6 & 490 & $\mathrm{~T}$ & - & - & 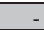 & - & 19 & 7 & 301 & \\
\hline 2009 & 21 & 6 & 555 & $\mathrm{~T}$ & 21 & 6 & 470 & $\mathrm{~A}$ & 18 & 6 & 410 & $\mathrm{~A}$ & 18 & 6 & 440 & $\mathrm{~T}$ & 24 & 6 & 390 & A & 21 & 6 & 255 & $\underline{S}$ \\
\hline 2010 & 24 & 6 & 490 & $\mathrm{~A}$ & 24 & 6 & 420 & $\mathrm{M}$ & 16 & 5 & 345 & $\mathrm{~A}$ & 16 & 5 & 410 & M & - & - & - & - & 20 & 6 & 260 & \\
\hline 2011 & 26 & 6 & 510 & $\mathrm{~A}$ & 26 & 6 & 480 & \begin{tabular}{|l|}
$X$ \\
\end{tabular} & 23 & 5 & 390 & $\mathrm{~A}$ & 28 & 5 & 375 & $\mathrm{~A}$ & 30 & 6 & 405 & $\mathrm{~A}$ & 19 & 4 & 235 & $\bar{S}$ \\
\hline
\end{tabular}

$\mathrm{A}=$ Thomas Andersson (37 surveys), $\mathrm{C}=$ Ulf T. Carlsson (27), $\mathrm{E}=$ Sophie Ehnbom (2), $\mathrm{G}=$ Martin Gierow (1), H = Lars Helsborn (1), I = Ingvar Lennerstedt (4), L = Göran Liljedahl (22), M = Anders Mathiasson (3), $\mathrm{N}=$ Lars Nilsson (1), $\mathrm{P}=$ Göran Paulson (2), $\mathrm{Q}=$ Ingvar Lennerstedt \& Alexander Hellquist (1), R = Roland Sandberg (2), S = Sören Svensson (91), T = Leif Lithander (14), X = Martin Green (1), Y= Magnus Stensmyr (1) 
Number of individuals of all species that were recorded along the survey lines in 1972-2011. For the rare species (name in bold), all records are listed in detail in this appendix. For the 38 most regular species (recorded in at least 20 of the forty survey years) the list shows number of years with records and total number of individuals actually counted, whereas the details are shown with diagrams in Figure 2. Code for the routes NA $=$ Nasen, $K R=$ Kraipe, RL $=$ Rusa Low, RH $=$ Rusa High, $\mathrm{R}=$ Raurejaure, ST = Stupipakte.

Antal individer av alla arter som noterats längs inventeringslinjerna 1972-2011. För de sällsynta arterna (namnet i fetstil) listas samtliga fynd i detta appendix. För de 38 mest regelbundna arterna (observerade minst 20 av de 40 inventeringsåren) visar listan antal år med observation och totala antalet individer som verkligen räknats, medan detaljerna visas $i$ diagrammen i Figur 2. Ruttkoder: $N A=$ Nasen, KR $=$ Kraipe, $R L=$ Rusa Low, $R H=$ Rusa High, $R=$ Raurejaure, ST $=$ Stupipakte.

Acrocephalus schoenobaenus Sedge Warbler Sävsångare: 1 ST 2011.

Actitis hypoleucos Common Sandpiper Drillsnäppa: 22 inds 1972-1983 (3, 1, 2, 0, 0, 4, 3, 3, 3, 1, 1, 1 inds respectively), 1 ind in each year 2003-2005, and 2 ind 2011. All routes represented but 16 of the individuals at the NA route in the first 12 years.

Alauda arvensis Eurasian Skylark Sånglärka: 1973(2), 74(3), 78, 83(2), 2001.

Anas acuta Northern Pintail Stjärtand: 2 RH 1977; 2 RA, 1 RH 1979; 1 NA 2001.

Anas crecca Common Teal Kricka: 34 years, 193 individuals.

Anas penelope Eurasian Wigeon Bläsand: 34 individuals in 14 years; almost all at RA and NA. Almost regular during the most recent decade.

Anas platyrhynchos Mallard Gräsand: 2 NA 1972; 2 RL 1993.

Anthus cervinus Red-throated Pipit Rödstrupig piplärka: 1 RL 1997; 1 RA 2000; 2 NA 2001; 1 KR 2003 ; 1 ST 2009.

Anthus pratensis Meadow Pipit Ängspiplärka: 40 years, 17572 individuals.

Anthus trivialis Tree Pipit Trädpiplärka: 2 RL 2005.

Aquila chrysaetos Golden Eagle Kungsörn: 17 ind in 11 yrs: 1975, 76, 82(2), 83(2), 89, 92(2), 98, 2003(2), 06, $07(3), 08$.

Asio flammeus Short-eared Owl Jorduggla: 18 inds in 9 yrs: 1981, 82, 86, 90(3), 91, 2001, 04(6), 05, 08(4), 10, 11(15).

Note the peak year 2011.

Aythya fuligula Tufted Duck Vigg: 25 years, 124 individuals.

Aythya marila Greater Scaup Bergand: 35 years, 152 individuals.

Bombycilla garrulus Bohemian Waxwing Sidensvans: 5 NA 2004, 5 NA 2005.

Bucephala clangula Common Goldeneye Knipa: 18 1972-1989, 11 1990-2008, difference not significant, 20 of the 29 at RA.

Buteo buteo Common Buzard Ormvråk: 1 ST 2009.

Buteo lagopus Rough-legged Buzzard Fjällvråk: 24 years, 89 individuals.

Calcarius lapponicus Lapland Longspur Lappsparv: 40 years, 11830 individuals.

Calidris alpina Dunlin Kärrsnäppa: 40 years, 1945 individuals.

Calidris temminckii Temminck's Stint Mosnäppa: 39 years, 192 individuals.

Carduelis flammea Common Redpoll Gråsiska: 40 years, 2165 individuals.

Carduelis hornemanni Arctic Redpoll Snösiska: 1 ST 1982; 1 ST 1988; 2 RH 1994.

Carduelis spinus Eurasian Siskin Grönsiska: 1 RH 2009.

Carpodacus erythrinus Common Rosefinch Rosenfink: 1 RA 2001; 1 RL 2002.

Charadrius hiaticula Common Ringed Plover Större strandpipare: 38 years, 184 individuals.

Charadrius morinellus Eurasian Dotterel Fjällpipare: 40 years, 407 individuals.

Chroicocephalaus ridibundus Black-headed Gull Skrattmås: 1 ST 2009.

Cinclus cinclus White-throated Dipper Strömstare: 1 1981, 1 1993, 1 1996; all at RA.

Circus aeruginosus Western Marsh Harrier Brun kärrhök: 2 ST 2004.

Circus cyaneus Hen Harrier Blå kärrhök: 16 inds in 11 yrs: 1976, 79, 82, 86, 90(3), 91, 93, 2003(2), 04, $06(3), 10$.

Clangula hyemalis Long-tailed Duck Alfågel: 33 years, 210 individuals.

Corvus corax Common Raven Korp: 40 years, 451 individuals.

Corvus corone Hooded Crow Kråka: 37 inds in 15 yrs: 12 in 5 yrs 1972-1978, 0 in 1979-80, 5 in 3 yrs in 1991-2001, 20 in all years 2002-2008; thus more common in the first and last years of the survey period.

Cuculus canorus Common Cuckoo Gök: 40 years, 367 individuals.

Emberiza schoeniclus Common Reed Bunting Sävsparv: 40 years, 93 individuals

Eremophila alpestris Horned Lark Berglärka: 36 inds in 7 years: 1972(9), 1973(11), 1974(2), 1975(3), 1976(4), 1977(6), 1980(1). 16 records at RH and 13 at RA. 
Falco columbarius Merlin Stenfalk: 17 inds in 13 yrs: 1971, 82, 86, 88(3), 89, 91, 92, 93, 94(2), 96(2), 2002, 03, 09 (records in 5 routes).

Falco peregrinus Peregrine Falcon Pilgrimsfalk: 1 RL 1986.

Falco rusticolus Gyr Falcon Jaktfalk: 1 NA 2000; 1 RA 2009, 1 RA 2010.

Falco tinnunculus Common Kestrel Tornfalk: 1 ind. in each of 1972, 76, 78, 81, 97, 2002, 07, 08, and 2 inds. in 2010, records at all routes.

Fringilla montifringilla Brambling Bergfink: 32 years, 147 individuals.

Gallinago gallinago Common Snipe Enkelbeckasin: 40 years, 872 individuals.

Gallinago media Great Snipe Dubbelbeckasin: 22 individuals in 15 years without trend and with records in all routes. There are several leks in the Ammarnäs area and the province is one of the best for the species (Ekblom \& Carlsson 2007), but as it is active at night we tend to miss many of the lekking individuals and record mainly the few that we flush.

Gavia arctica Black-throated Loon Storlom: 24 inds. in 15 years, all but one at RA in 1972-1992, representing one breeding pair in Raurejaure.

Gavia stellata Red-throated Loon Smålom: 2 ST 1996; 1 ST, 2 RA 2001; 2 RA 2003; 1 ST 2007; 1 RA 2010 ; 2 RA 2011.

Grus grus Common Crane Trana: 2 ST 2007; 1 ST 2010; 2 ST 2011.

Haliaeetus albicilla White-tailed Eagle Havsörn: 2 RH 2007; 2 RA 2008.

Hirundo rustica Barn Swallow Ladusvala: 1 RL 2009; 1 RH 2009.

Lagopus lagopus Willow Ptarmigan Dalripa: 36 years, 176 individuals.

Lagopus muta Rock Ptarmigan Fjällripa: 38 years, 197 individuals.

Larus argentatus Herring Gull Gråtrut: 1 NA 1996; 1 KR 2001.

Larus canus Mew Gull Fiskmås: 40 years, 708 individuals.

Limosa lapponica Bar-tailed Godwit Myrspov: 1 ST, 1 NA 1988; 1 RH, 1 NA, 1 KR 2003; 3 RH 2004; 1 ST, 1 RH 2006 ; 1 ST 2008; 2 ST, 3 RA, 1 NA 2011.

Loxia sp. Crossbill Korsnäbb obestämd: 1 NA 1972.

Luscinia svecica Bluethroat Blåhake: 40 years, 1012 individuals.

Melanitta fusca Velvet Scoter Svärta: 32 years, 143 individuals.

Melanitta nigra Black Scoter Sjöorre: 35 years, 211 individuals.

Mergus merganser Goosander Storskrake: 28 individuals in 14 years: 1977, 80, 83, 85, 86, 89, 90, 93(5), 97, 99, 2007(5), 08(2),09,10(6).

Mergus serrator Red-breasted Merganser Småskrake: 1 NA 1980; 1 RA 2003-04; 2 RA 2006.

Motacilla flava Yellow Wagtail Gulärla: 1 RH 1980; 2 RL 1987; 1 KR 1989; 2 RL, 1 RA 1992; 1 RA 1995; 1 ST 1999 ; 1 KR 2002; 1 ST 2007.

Numenius phaeopus Whimbrel Småspov: 34 years, 158 individuals.

Oenanthe oenanthe Northern Wheatear Stenskvätta: 40 years, 1428 individuals.

Phalaropus lobatus Red-necked Phalarope Smalnäbbad simsnäppa: 40 years, 692 individuals.

Philomachus pugnax Ruff Brushane: 36 years, 363 individuals.

Phoenicurus phoenicurus Common Redstart Rödstjärt: 1 ST 2010; 1 ST 2011.

Phylloscopus trochilus Willow Warbler Lövsångare: 40 years, 4697 individuals.

Plectrophenax nivalis Snow Bunting Snösparv: 21 years, 126 individuals.

Pluvialis apricaria European Golden Plover Ljungpipare: 40 years, 7053 individuals.

Prunella modularis Dunnock Järnsparv: 1 RA 1973; 2 (ST, RA) 1975; 1 ST 1978; 2 RA 2009; 3 RL 2011.

Saxicola rubetra Whinchat Buskskvätta: 1 NA 1972; 1 RL 1991; 1 ST 2009.

Stercorarius longicauda Long-tailed Skua Fjällabb: 39 years, 2116 individuals.

Sterna hirundo Common Tern Fisktärna: 1 RA 1997.

Sterna paradisaea Arctic Tern Silvertärna: 29 years, 78 individuals.

Tringa erythropus Spotted Redshank Svartsnäppa: 1 RA 1982; 1 KR 1987; 1 RA 1998; 1 KR 2008; 2 ST 2010.

Tringa glareola Wood Sandpiper Grönbena: 33, 259 individuals.

Tringa nebularia Common Greenshank Gluttsnäppa: 23 years, 72 individuals.

Tringa totanus Common Redshank Rödbena: 40 years, 701 individuals.

Turdus iliacus Redwing Rödvingetrast: 40 years, 902 individuals.

Turdus philomelos Song Thrush Taltrast: 31997 at ST, RA, NA.

Turdus pilaris Fieldfare Björktrast: 36 years, 610 individuals.

Turdus torquatus Ring Ouzel Ringtrast: 29 years, 60 individuals.

Vanellus vanellus Northern Lapwing Tofsvipa: 1 RA 1997. 